\title{
TRANSFORMATION OF LEISURE TIME IN NEW MEDIA: BINGE WATCH
}

\author{
Asc.Prof.Dr. Deniz Yengin \\ İstanbul Aydın University, İstanbul \\ denizyengin@aydin.edu.tr \\ Lecturer Ömür Kınay \\ İstanbul Kültür University, İstanbul \\ omurkinay@gmail.com
}

\begin{abstract}
Communication has been in existence since the beginning of human history. It is impossible to think of communication without humans, and humans without communication. Throughout time, individuals have developed their communication skills. By obligation to these developments, the environment where the message is tranferred also changes. Media is updated everyday with technical novelties. Bolter's statement "each improvement is a mediation" models the transformation in media and new media. Content, relationships and interaction in new media are mediations, while what concerns systems and technology is considered as remediation. The increase in content and interaction in the media, and the update of relationships creates mediation. The transformation in the technological substructure of the media is expressed as remediation. The most obvious example to give is television. Television has had a linear communication process as a conventional media tool. However, television has undergone the processes of remediation and mediation, where it has now incorporated an interactive structure. With characteristics such as internet, 3 dimensions, digitalization, high resolution, television can now be characterized as 'smart'. Technology, which is defined as socialized information, has turned television into an interactive system. Due to this novelty, television watching habits are changing. In this context, new terminology is also emerging. This study examines binge watching, as a new television watching habit as a result of television's changing characteristics. This study further examines the concept of binge watching according to the uses and gratification theory, where New Media practices have transformed television show watching patterns as a free time activity. In the study, the concept is discussed through a literature review and evaluated through a survey prepared to understand individual television show watching habits.
\end{abstract}

Keywords: new media, leisure time, uses and gratifications theory, binge watch

\section{YENI MEDYADA BOŞ ZAMANIN DÖNÜŞÜMÜ: TIKINMALI IZLEME}

\section{ÖZ}

İletişim, insanlık tarihiyle hayat bulmuştur. İletişimi insansız, insanı da iletişimsiz düşünmek imkansızdır. Bu süreçte birey sürekli iletişim kurma becerilerini geliştirmektedir. Bu gelişim de beraberinde iletiyi aktaran ortamın sürekli yenilenmesini zorunlu kılmaktadır. Medya, teknik yeniliklerle birlikte güncellenmektedir. Bolter "her iyileştirme bir arabuluculuktur" söylemiyle medyanın, yeni medyaya dönüşümünü modellemektedir. Bu noktada; medya üzerinde içerik, ilişkiler ve etkileşim özellikleriyle iyileştirme(mediation); teknoloji ve sistemlerle de yenileme(remediation) gerçekleşmektedir. Medyada yer alan içeriğin ve etkileşimin artması ve ilişkilerin kendini güncellemesiyle iyileştirme(mediation) gerçekleşmektedir. Medyanın teknolojik altyapılarını yaşanan ortamdaki tekniğe göre dönüştürmesi ise yenileme olarak ifade edilmektedir. Bu duruma verilebilecek en belirgin örnek televizyondur. Konvansiyonel medya olarak televizyon çizgisel bir iletişim sürecine 
sahipti. Ancak, yenileme(remediation) ve iyileştirme(mediation) süreçlerinden geçen televizyon günümüzde interaktif bir yapıya dönüşmüştür. İnternet, üç boyutluluk, dijitallik, yüksek çözünürlük özellikleriyle televizyon, akıllı (smart) olarak nitelendirilmektedir. Sosyalleşmiş bilgi olarak tanımladığımız teknoloji televizyonu da etkileşimli bir sisteme dönüştürmüştür. Etkileşimli yapısıyla televizyonda izleme alışkanlıkları da güncellenmektedir. Bu bağlamda birbirinden farklı terminolojiler de ortaya çıkmaktadır. Bu çalışmada da yeni medya olarak televizyonla birlikte ortaya çıkan yeni dizi izleme alışkanlıklarından biri olan "tıkınmalı izleme (binge watch)" edimi incelenmektedir. Kullanımlar ve doyumlar yaklaşımı bağlamında boş zaman aktivitesi olarak dizi izleme alışkanlığının yeni medyayla farklı pratiklere dönüşümü olarak "tıkınmalı izleme" kavramı incelenmektedir. İncelemede literatür taramasıyla birlikte tartışılan bu kavram tanımlanmakta ve bu tanım 1şığında hazırlanan anket doğrultusunda bireyin dizi izleme alışkanlık ve tutumları değerlendirilmektedir.

Anahtar Kelimeler: yeni medya, boş zaman, kullanımlar ve doyumlar kuramı, tıkınmalı izleme

\section{INTRODUCTION}

Communication is a basic element that forms society. Communication is a "product of the way humans lead their existences and is a notion specific to humans that undergoes transformation according to the changes that occur in their existences". Communication, which is expressed as a notion specific to humans, defines social relationships as a whole. The notion of communication arose from the necessities of humans and has developed over time, entering our lives in many different ways (Oskay, 1997:7). Communication is a word that derived from common, meaning united. The word communication has a close relationship with Community, society, and social sharing and, over time, the meaning of the word spread and has come to express common information, common emotion, common sensibility, and common point of view (Güngör, 2013:39). In this context, communication is the relationship the individual foms with its environment. This relationship widens when individuals make use of mass media. While mass media did not used to be a defining factor for the the operation of communication, which is the foundation of communication studies, today, it has become essential. McLuhan evaluates this situation by underlining the fact that the mean is also a message. McLuhan's (1983) "the medium is the message" phrase references technology. Technology has been present in every period and is continuing to be one. "For example industrialization from the printing press, paper, to ink has changed the direction of human history, and has provided important developments that have defined the fate of societies" (Güngör, 2011:109). The medium, which is an essential part of the communication process, is updated along with technology. At this point, a definition of the notion of technology gains importance.

In this regard, many of the things humans produce in order to live and that are around them are technology related. According to Marx, technology "is the way in which humankind overcomes nature. Technology is a tool, an application and constituent parts that carry out human goals, and it is the total of the tools and engineering applications at the hands of a culture. In short technology is a programming of phenomena to our purposes." (Arthur, 2011:36). Furthermore, "technology is constructed for some specific purpose; can be mechanical, thermal, electrical or digital; is artificial rather than natural; automates human labor; and is a natural human capacity" (Lister, 2009:320-321). Taking these definitions into consideration then, technology can shortly be said to be a systematic, useable and social information.

Ellul evaluates the concept of technology from a critical perspective:

The technological society states that anything that is not technical in society is bound to be excluded. It has been noticed that society is turning into a slave of technique as a result of scientific and technological developments. "Technique requires predictability and, no less, exactness of prediction. It is necessary, then, that technique prevail over the human being. For technique, this is a matter of life or death. Technique must reduce man to a technical animal, the king of the slaves of technique. Human caprice crumbles before this necessity; there can be no human autonomy in the face of technical autonomy. The individual must be fashioned by techniques, either negatively (by the 
techniques of understanding man) or positively (by the adaptation of man to the technical framework), in order to wipe out the blots his personal determination introduces into the perfect design of the organization" (Ellul, 2003:149).

The concept of technology has appeared before us throughout time and each novelty has been defined as technology. At this point, technology has updated and digitalized the communication process. The fact that media is expressed as 'new' is an indicator of technological novelty. Communication is mandatory for individuals and, at each renewal of technology, the individual has to update itself. In order to understand the obligatory need for these tools by individuals, it is important to clarify the "uses and gratification" theory.

\section{USES AND GRATIFICATIONS THEORY}

Communication is neccessary for the individual. Through communication, the individual finds solution to its needs. Mass media is used in order to overcome these needs. At first, communication studies focused on how mass media in the communication process effected the individual. With time, studies on why the individual used mass media started to be conducted. The Uses and Gratification Theory is one such study. This theory is a commucation model that supposes audience members effectively try to find mass media content that more or less gratify their needs. It is a model that focuses on the problematic of what people do with mass media. Its focus is not the mean, but the person utilizing that mean. This model, which brings to the fore the needs and motivations of audiences, focuses on the following questions: "how do needs come to be gratified and lead to other conclusions; what are the social and psychological roots of the needs that lead to expectations from mass media and other sources and that leads to the different uses of mass media?" (Mutlu, 2008:190).

"The uses and gratification theory defends the position that audiences make use of mass media in an effective manner. This typology which was development from a functionalist stance, answers to the question of why audiences watch television by defining the process of watching not as passive but as one where there is active participation" (Mutlu, 1999:81).

Katz (1959) brings attention to what individuals do with mass media, as opposed to what the mass media does to individuals. Klapper (1963) describes the development of the uses and gratification theory as follows: "we used to boast that our research asked the question "what does mass media do to individuals?", however now, the uses and gratification theory asks a more meaningful question: "What does an individual do with mass media?" Here, the sender's domination ends and the receiver' begins. According to this approach, people use mass media tools in order to fulfill their needs. They choose from these tools and the products of these tools in order to fulfill their needs. As a result of this purposeful activity needs are fulfilled and stress is reduced" (as cited in Erdoğan and Alemdar, 2005:161).

Rosengren (1974) also discusses the uses and gratification theory and the relationship of related factors. These factors are; (a) the basic biological and psychological human needs; (b) personal and social characteristics of individuals; (c) the structure of society, (d) personal problems; (e) problem solving that comes to mind; (f) motivations behind problem solving or search for satisfaction; (g) media consumption; (h) other behaviors; (i) satisfaction molds and molds beyond; (j) the effects on individual characteristics; $(\mathrm{k})$ the effects on social structure (for example: media strcutures, social structures, political, cultural and economic structures) (as cited in Rubin 1986: 285). "Individual needs form the starting point of Rosengren's model. In order for these needs to turn into acts, they have to be perceived as problems. Furthermore, a set of analysis also needs to be perceived according to the model. Another important point that is underlined according to this model is the formative role played by the social structure and individual characteristics on needs. The perception of the problems and the possible solutions to them lead to a form of motivations towards the use mass media tools and other behavior types. In the end, needs present at the beginning can either be satisfied or not" (McQuail and Windahl, 2010:169). 
Table 1. The social origin of audience needs and the media

\begin{tabular}{|l|l|}
\hline \multicolumn{1}{|c|}{$\begin{array}{c}\text { The social origin of audience needs } \\
\text { The social situation: }\end{array}$} & \multicolumn{1}{c|}{ Media provide } \\
\hline Produces tension and conflict & Easement \\
\hline $\begin{array}{l}\text { Creates awareness of problems that demand } \\
\text { attention }\end{array}$ & Information \\
\hline $\begin{array}{l}\text { Impoverishes opportunities to satisfy certain } \\
\text { needs }\end{array}$ & $\begin{array}{l}\text { Complementary, substitute, or } \\
\text { supplementary servicing }\end{array}$ \\
\hline Gives rise to certain values & Affirmation and Reinforcement \\
\hline $\begin{array}{l}\text { Provides expectations of familiarity with certain } \\
\text { media materials }\end{array}$ & $\begin{array}{l}\text { Shared experience to sustain } \\
\text { membership of valued social groupings }\end{array}$ \\
\hline
\end{tabular}

(Source: Fiske, 2013:273)

According to Katz, people have socially and psychologically rooted needs. As a result of these needs, people start having certain expectations from the media and other sources in order to fulfill these needs and, due to their exposure to media, they are able to satisfy certain of these needs. According to this approach, it can be accepted that there is a functional relationship between media content and audiences. However, the messages spread by mass media are not consumed in a free and problemless manner; they are consumed in the way media institutions present them to the public (Yaylagül, 2010:70-71).

According to the uses and gratification theory, the members of the audience are active. This theory asserts that audience members take on an active role, as they choose information given to them by the media and use this information in order to satisfy their needs. Katz, Gurevitch, and Haas (1973) argue that audience members open to the media, in order to satisfy psychological and social needs. Rosengren states that individuals search for solutions with regards to certain problems that they have in their relationships in their social environments, in the media.

Severin and Tankard believe that people use the media for several different reasons and that this use is under the supervision of the user. The uses and gratification theory is a healthy antidote to previous research that has always put the viewer in a passive position. Due to the intensity of the information received from the media nowadays, the position of active viewer has faced more and more alternative approaches. (Severin ve Tankard, 1994: 492-493).

In summary: the uses and gratification theory provides a platform for the research of audience reactions, where they especially focus on the individual's consumption of the media. Instead of asking the question of what the media does to people, the theory focuses on what people do with media. Within the frame of this research question, the use of new media in the rapidly digitalized free time of individuals gains importance.

\section{TRANSFORMATION OF LEISURE TIME}

Aristotle argued that being free is the principle of the universe and the goal of work. However, he also noted that this did not mean using free time in a meaningless and aimless manner. He believed that free time, which he expressed as Diagoge, should be used to educate (paideia) oneself (Oskay, 2000:146). The possibility of this depends on the individual's consciousness and level of freedom. Free time should not be spend doing meaningless things, but should be a conscious and for educational and elevatory goals. This essentially depends on the individual's level of freedom and consciousness.

Adorno's essay entitled "Leisure Time", argues that free time is simply an add-on to profit-driven life, and thus becomes its own opposite, a parody of itself; free time is subjected to the norms of the production process. Adorno explains this through the hobby ideology, which states that everyone should have a hobby. This is why free time has become more and more exposed to social surveillance. In addition to this approach, Smythe states that for most people, work takes up twenty four hours of 
the day (Mosco ve Fuchs, 2014:339). Audience activities are commodified by the capitalist system and produce value; in return, audiences are given what appears to be a free meal. Pleasure, which is the source of happiness in the culture industry, is possible only through the imprisonment of cultural goods to a certain understanding of entertainment This understanding of entertainment, removes pleasure as the source of happiness, and makes this time free of work, into a time to run to work. Entertainment becomes a form of comfort. In late capitalism, this form of entertainment is an extension of work.

In order to gather the strength to deal with the mechanized work process, entertainment is pursued. However, mechanization has such a force over free time and happiness, that it has defined the production of entertainment goods (Kejanlıoglu, 2005:186). The digitalization of free time through the use of the internet has led to the rapid emergence of new forms of free time. The notion of free time that has enclosed modern societies has become one of the basic values. Individuals give a lot of importance to the free time they have left outside of working hours. According to Cuenca, free time is "a human experience that is satisfying, but that is not perceived as obligatory or mandatory for the subject. Its aim is hidden within it, free and satisfactory; it is a basic need, separate from emotional and psychical needs." The individual in today's capitalist system does not live to work, but works in order to enjoy free time (Blanco, 2014:186-190).

According to Anders, contemporary media consumption is the total of individual applications; each consumer is an unpayed home laborer working for the production of mass society. Individuals consume free time products at a very high level. Individuals become dehumanized under the guise of entertainment, where they are left without the qualities that make them human. Mass media tools allow for us to see the world. Thanks to these tools, events come to us, we no longer go to them. According to Anders individuals are not in the world; they are indifferent and passive consumers outside of the world. For the individual, the world is lived through images. The difference between reality and the production of reality is removed through the reproduction of real events. In short, we learn of what is happening around the world through mass media tools in our homes (Türkoğlu, 2012:23). The primary goal of the information, entertainment and educatoinal materials in the media is to engage the attention of the audience towards the advertisement of products and services.

People who are pursuing their personal interests in their free time, cannot participate in social or political activies. According to Smythe, mass media has been developed by monopolistic capitalism. The aim being to teach people consumption, to provide support to the system by voting and paying taxes and, as a result of this support, for the system to gain profit (Yaylagül, 2010:164). The more free time, the more the social individual becomes productive. Free time allows for the social individual and culture in general to develop and creates a culture where there are more and more needs (Mosco ve Fuchs, 2014:238). In paralel to technological developments, the understanding of digital free time has come about. Time is now a timeless time, and spaces are defined by flows and connections. This new free time practice takes place in "instant" and "timeless" virtual spaces.

What comes to the fore in digital free time is accelaration, brief enjoyments, temporality, the weakness of people's limits and continuous uncertainty. Technology has transformed the way in which people access free time, as well as their free time behaviours and experiences. Computers, smart phones and tablets, along with other technological devices have created a perfect screen for the free time space. We could spend our free time reading a book. Reading an electronic book can be defined as the digitalization of the traditional. Joining a virtual community is an activity lived on the network. Thus, both a transformation and a new activity come about (Blanco, 2014:191-193). 
Table 2: An Approach to the concept of "Digital Leisure Time"

\section{Digital Leisure Time}

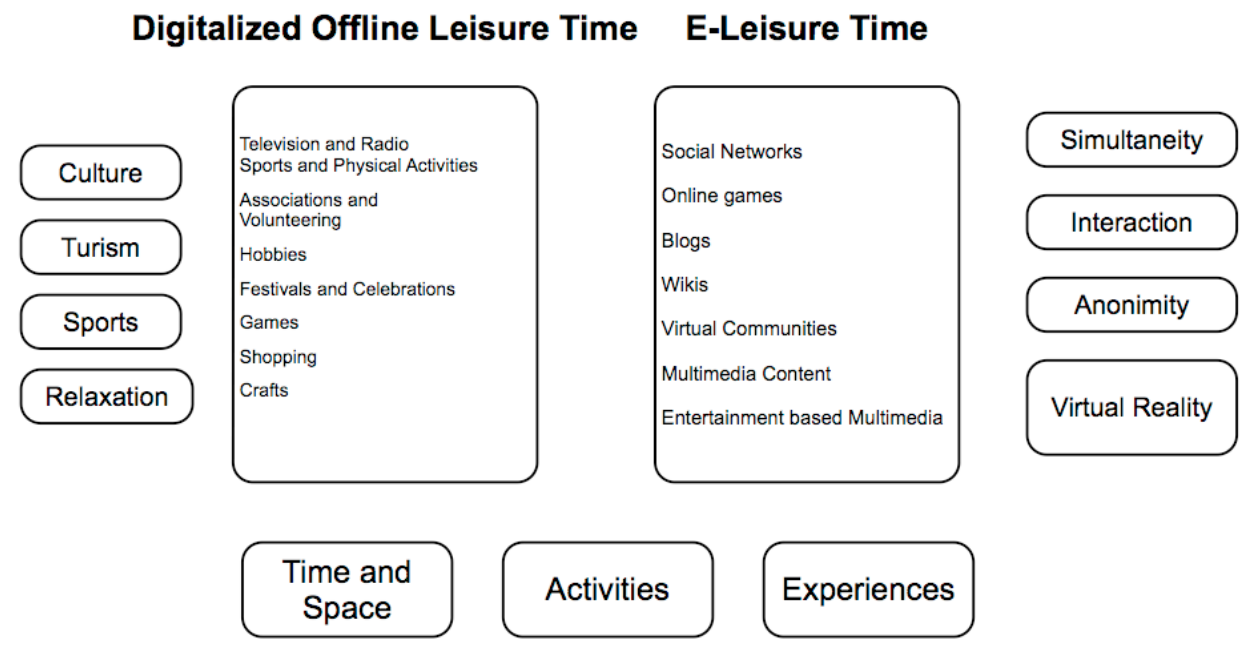

(Source: Blanco, 2014:194)

The digital free time online can be interpreted as a state of being dependent, as opposed to not being dependent. Digital free time is the state of being dependent to a digitally formed social world. It is not putting the virtual version of that which is real, it is the formation of a new space in order to uphold social relationships (Blanco, p.195). Digital free time can be divided into two: Digitalized Offline Free Time and E-Free Time. Activities such as culture, tourism, sports and relaxation can be seen as digital activies that are conducted offline. Characteristics such as simultaneity, interaction, anonimity and virtual reality define e-free time. There is a transformation from offline free time and online free time. What is important here is not virtuality, but what needs to be payed attention to is the formation of a new space in order to uphold social relationships (Table 2). Digital free time is a type of free type that governs the $21^{\text {st }}$ century. Network communities that have timeless times and fluid spaces have led to a change in the way free time is evaluated. The digitalization of experience is shown to be like a new invention. Digital free time experiences allow for disengagement from the stress of daily life, and provide people with positive time forms that they can use for their personal growth and fun (Blanco, 2014:199). In short, digital free time is the realization of daily activities in a digital space. With its digital characteristics, new media is constantly used by individuals and allows for them to live online. However, Bauman's fluid space and time concepts are taking individuals under control. Thus, individuals are embracing their digital identities more than ever. This appropriation transforms the individual's free time activies and through this transformation, these habits are updated. This study will analyze the concept of "binge watching" as a form of free time activity that has transformed television show-watching.

\section{THE CONCEPT OF "BINGE WATCHING"}

Television creates a cultural consensus with regards to the nature of reality. By incorporating individuals into the dominant system of values, they, by default, become part of social hegemony. This is effective on individual identity, status and roles, as they redefine role expectations and reformulate daily life behaviours.

The spread of postmodernist tendencies through the media and culture industries are being strengthened by communication environments and intercultural communication, which are leading to cultural mutation and hybridisation to become more prominent. (Önür, 2012:282-288). In order for television companies to survive, they need to produce media products. At this conjuncture, television shows call attention. In the United States, people are able to access more and more digital broadcasts. 
People now prefer watching television broadcast on the internet, where they can access them all at once. The changing viewing habits in television shows allow for individuals to have control and decide when, where and what they want to watch. In the United States, websites that offer easy access such as Netflix, Hulu and Amazon Instant Video, as well as tools such as Apple TV and Amazon Fire $\mathrm{TV}$, allow for the viewing of television shows and films one after the other, leading to a change in viewing habits. Bing watching can be defined as watching videos or television shows in one sitting.

Television viewing patterns are changing radically. People want to have control over what, where, when and through which mean they watch what they watch and thus prefer the bing watching alternative when watching television shows. These changes in viewing patterns have also come about due to the increase in digital access possibilities and applications such as "programs on demand". Instead of waiting for the episode of a television show to come out every week, they prefer watching the episodes in one sitting. This viewing method is called "binge watching", where viewers sit down and watch a couple or all the episodes of a television show in one go. In the last quarter of 2013, the company that has grabbed the most attention was Netflix, with its 2.3 million new members and 50 million dollar net profit. Netflix provides online media access in countries such as the United States, England Holland, Denmark, Norway, Sweden and Turkey. At the beginning of 2010, especially after the spread of high speed internet, Netflix led to the bankrupcy of Blockbuster, the biggest DVD rental company in the United States. Now, Netflix is even a threat to traditional television broadcasting channels, such as HBO, AMC and Showtime. The progress Netflix has recorded recently even surprises those analyzing the industry from up close. Since the beginning of 2014, Netflix has gained nearly $30 \%$ of increase in value, reaching a value of 26,5 million dollars. Netflix members are not only viewers, but they are users that can choose what they watch and this gives hope for the future of the company in the industry. The time a cable broadcast television channel can reserve for a program is more limited compared to Netflix.

(Date Accessed: 28.03.2014, http://www.gazetebilkent.com/2014/03/01/televizyon-tahtini-almayahazirlanan-dev-netflix/).

Another novelty Netflix has brought to the field of broadcasting is the possibility to binge watch television shows. Instead of waiting for a new episode to come out weekly, through this playform viewers can now watch any episode of any season they want without waiting, offering a new alternative for television broadcast viewers. Having the advantage of being financially less risky, television is a space where stories, thought never to be told, can now be told. One of the fields in which technology giants are competing to advance in, is the possibilities regarding televisions to relay online broadcasting. The resulting technology is a box which has its own operating system that works via the internet and which is compatible with every television brand. The box can hold content such as games, applications, films and music. The content can be accessed via the internet. Although some of the content is offered free of charge, other content such as films, music and games can be accessed via online payments. One of the most important characteristics of these online broadcast boxes is the possbilities to reflect what is on the computer, smart phone or tablet on to the television screen without cable.

(Date Accessed: 10.04.2014,

http://hurarsiv.hurriyet.com.tr/goster/haber.aspx?id=26162305\&tarih=2014-04-06 ).

Table 3. Domestic(Turkey) and Global Television Broadcast Durations

\begin{tabular}{|c|c|c|c|}
\hline \multicolumn{2}{|c|}{ Global Television Shows } & \multicolumn{2}{c|}{ Domestic Television Shows (Turkey) } \\
\hline Television Show & $\begin{array}{c}\text { Total } \\
\text { Duration }\end{array}$ & Television Show & Total Duration \\
\hline Homeland & $\begin{array}{l}1 \text { day and } 3 \\
\text { hours }\end{array}$ & Muhteşem Yüzyıl & $\begin{array}{l}10 \text { days and } 22 \\
\text { hours }\end{array}$ \\
\hline
\end{tabular}


The Turkish Online Journal of Design, Art and Communication - TOJDAC January 2017 Volume 7 Issue 1

\begin{tabular}{|l|l|l|l|}
\hline Game of Thrones & $\begin{array}{l}1 \text { day and } 6 \\
\text { hours }\end{array}$ & Yaprak Dökümü & $\begin{array}{l}10 \text { days and 2 } \\
\text { hours }\end{array}$ \\
\hline The Walking Dead & $\begin{array}{l}1 \text { day and } 15 \\
\text { hours }\end{array}$ & Ezel & $\begin{array}{l}4 \text { days and 23 } \\
\text { hours }\end{array}$ \\
\hline Modern Family & $\begin{array}{l}1 \text { days and 19 } \\
\text { hours }\end{array}$ & Aşk-1 Memnu & $\begin{array}{l}4 \text { days and 21 } \\
\text { hours }\end{array}$ \\
\hline Breaking Bad & $\begin{array}{l}1 \text { days and 22 } \\
\text { hours }\end{array}$ & Kuzey Güney & $\begin{array}{l}6 \text { days and } 11 \\
\text { hours }\end{array}$ \\
\hline Mad Men & $\begin{array}{l}2 \text { days and } 9 \\
\text { saat }\end{array}$ & İşler Güçler & $\begin{array}{l}2 \text { days and } 14 \\
\text { hours }\end{array}$ \\
\hline The Big Bang Theory & $\begin{array}{l}2 \text { days and 13 } \\
\text { hours }\end{array}$ & Seksenler & $\begin{array}{l}8 \text { days and 2 } \\
\text { hours }\end{array}$ \\
\hline How I Met Your Mother & $\begin{array}{l}3 \text { days and 2 } \\
\text { hours }\end{array}$ & Avrupa Yakas1 & $\begin{array}{l}10 \text { days and } 13 \\
\text { hours }\end{array}$ \\
\hline Lost & $\begin{array}{l}3 \text { days and } 18 \\
\text { hours }\end{array}$ & Yalan Dünya & $\begin{array}{l}5 \text { days and } 5 \\
\text { hours }\end{array}$ \\
\hline 24 & $\begin{array}{l}6 \text { days and 2 } \\
\text { hours }\end{array}$ & Behzat Ç. & $\begin{array}{l}5 \text { days and 21 } \\
\text { hours }\end{array}$ \\
\hline
\end{tabular}

Source: http://nielsentopten.com/2014/04/29/just-how-long-is-a-tv-marathon/ (Global Series)

(This is data collected up until the date: 15.06 .2014 )

The concept of binge wathing supports the reality that with the internet, sharing too has become faster. Watching television show episodes one after the other has become more and more widespread with new media. Table 3 details the total time of global and local television shows. The amount of time spend if each episode is watched one after the other for each show is calculated. Table 3 demonstrates binge watching practices, evdident when looking at the total time indicated for popular global and local television shows. For example, if we want to binge watch the television show Muhteşem Yüzyıl, starting today, we would have to sit in front of a computer or television screen and watch it nonstop for 11 days. Here, the level of activity the viewer engages in is important. What renders binge watching popular is the fact that decision-making is entirely in the hands of the viewer.

\section{METHODOLOGY}

Communication has been in existence since the beginning of human history. It is impossible to think of communication without humans, and humans without communication. Throughout time, individuals have developed their communication skills. By obligation to these developments, the environment where the message is tranferred also changes. Media is updated everyday with technical novelties. Bolter's statement "each improvement is a mediation" models the transformation in media and new media. Content, relationships and interaction in new media are mediations, while what concerns systems and technology is considered as remediation. The increase in content and interaction in the media, and the update of relationships creates mediation. The transformation in the technological substructure of the media is expressed as remediation. The most obvious example to give is television. Television has had a linear communication process as a conventional media tool. However, television has undergone the processes of remediation and mediation, where it has now incorporated an interactive structure. With characteristics such as internet, 3 dimensions, digitalization, high resolution, television can now be characterized as 'smart'. Technology, which is defined as socialized information, has turned television into an interactive system. Due to this novelty, 
television watching habits are changing. In this context, new terminology is also emerging. This study examines binge watching, as a new television watching habit as a result of television's changing characteristics. This study further examines the concept of binge watching according to the uses and gratification theory, where New Media practices have transformed television show watching patterns as a free time activity. In the study, the concept is discussed through a literature review and evaluated through a survey prepared to understand individual television show watching habits.

\section{Demographic Findings}

The survey consists of 26 close-ended questions. Four of these questions measure demographic characteristics, while the 22 others are related to the changes in television show watching habits. The ordinale scale was used for the questions related to binge watching. The survey was prepared with the aim of understanding how viewing habits have changed with the advent of new media. The demographic questions on the survey collect data with regards to individual gender, age range, educational level and occupation. Questions relating to viewing habits measure individual user information. The other questions are directed towards learning about viewing habit transformation. The five-point Likert scale was used for the questions in this section. This survey was prepared with the "New Media is transforming your television watching habits" problematic in mind, where the answers of 441 people were analyzed. The findings with regards to the 441 research participants can be seen in Table $4.56 .9 \%$ of participants are women, $43.1 \%$ men, $40.1 \%$ of them are between 19 to 24 years old, $62.1 \%$ of them have an undergraduate degree, while $47.2 \%$ of them are still students.

Table 4. Charactertics of the Reseach Participants

\begin{tabular}{|c|c|c|}
\hline Groups & Frequency $(n=441)$ & Percentage (\%) \\
\hline \multicolumn{3}{|l|}{ Gender } \\
\hline Female & 251 & 56.9 \\
\hline Male & 190 & 43.1 \\
\hline \multicolumn{3}{|l|}{ Age } \\
\hline Between $13-18$ years old & 16 & 3.6 \\
\hline Between $19-24$ years old & 177 & 40.1 \\
\hline Between $25-30$ years old & 107 & 24.3 \\
\hline Between $31-36$ years old & 85 & 19.3 \\
\hline 37 years old and above & 56 & 12.7 \\
\hline \multicolumn{3}{|l|}{ Educational Level } \\
\hline Primary School & 2 & 0.5 \\
\hline Middle School & 24 & 5.4 \\
\hline Vocational School & 17 & 3.9 \\
\hline Undergraduate degree & 274 & 62.1 \\
\hline Master's degree & 83 & 18.8 \\
\hline Doctoral degree & 41 & 9.3 \\
\hline \multicolumn{3}{|l|}{ Occupation } \\
\hline Payed & 117 & 26.5 \\
\hline Freelance & 43 & 9.8 \\
\hline Unemployed & 25 & 5.7 \\
\hline Student & 208 & 47.2 \\
\hline Other & 48 & 10.9 \\
\hline
\end{tabular}

The findings with regards to television show watching habits of participants can be seen. $98.6 \%$ of participants express that they watch television shows; $68.7 \%$ of those viewers watch foreign television shows. $50.3 \%$ of the participants watch 1 or 2 television shows per week, while $40.1 \%$ of them state that they watch the shows on television. $40.6 \%$ said they used online websites, $49.1 \%$ stated following 1 or 2 television shows, $77.3 \%$ saying that they did not watch the reruns of television shows, $77.8 \%$ of 
participants said that the topic of the television show was important in deciding which show to watch, and $65.8 \%$ of participants expressed watching television show episodes one after the other.

\section{Factor Analysis}

Scales have been developed in order to measure the relationship between concepts in social sciences. Factor analysis is a prevalent method. Factor analysis is a statistical method of analysis that faciliates the understanding and the interpretation of the relationship between multiple observed variables.Depending on the relationship between the questions, factor analysis is a method of analysis that aims to facilitate and understand the numerous variables by reducing and summarizing them to their basic dimensions. What is important here is to decrease the number of variables in order to facilitate interpretation. (Altunış1k, 2005:212-231).

Table 5. Factor Analysis belonging to the Scale and the Factor Weights that have come out.

\begin{tabular}{|c|c|c|c|}
\hline $\begin{array}{l}\text { Name of } \\
\text { Factor }\end{array}$ & Items & $\begin{array}{l}\text { Factor } \\
\text { Weights }\end{array}$ & $\begin{array}{l}\text { Explonatory } \\
\text { Factor }(\%)\end{array}$ \\
\hline \multirow{5}{*}{ Factor 1} & $\begin{array}{l}\text { It makes me happy to be in control when binge } \\
\text { watching. }\end{array}$ & 0.839 & \multirow{5}{*}{26.136} \\
\hline & $\begin{array}{l}\text { I watch the episodes of a television show one after the } \\
\text { other (binge watching) once the season is over. }\end{array}$ & 0.767 & \\
\hline & $\begin{array}{l}\text { When I watch the episodes of a television show one } \\
\text { after the other (binge watching), I can concentrate on } \\
\text { the topic more easily. }\end{array}$ & 0.765 & \\
\hline & $\begin{array}{l}\text { I understand the topic of television shows more easily } \\
\text { thanks to binge watching. }\end{array}$ & 0.755 & \\
\hline & $\begin{array}{l}\text { Instead of watching episodes weekly, I prefer to save } \\
\text { them and watch them all at once. }\end{array}$ & 0.711 & \\
\hline \multirow{5}{*}{ Factor 2} & $\begin{array}{l}\text { My cultural knowledge increases thanks to television } \\
\text { shows. }\end{array}$ & 0.755 & \multirow{5}{*}{20.187} \\
\hline & I follow television shows episode by episode & 0.729 & \\
\hline & $\begin{array}{l}\text { I watch any television show I begin until the season } \\
\text { finale. }\end{array}$ & 0.699 & \\
\hline & $\begin{array}{l}\text { I can see the development of characters as I watch a } \\
\text { television show. }\end{array}$ & 0.638 & \\
\hline & $\begin{array}{l}\text { Foreign television shows help my foreign language } \\
\text { skills. }\end{array}$ & 0.553 & \\
\hline \multirow[t]{2}{*}{ Factor 3} & Binge watching can sometimes be tiring. & 0.837 & \multirow[t]{2}{*}{10.328} \\
\hline & When I watch television shows, I escape daily life. & 0.516 & \\
\hline \multirow{2}{*}{\multicolumn{3}{|c|}{$\begin{array}{r}\text { Total } \\
\text { Kaiser - Meyer - Olkin Sample Sufficiency }\end{array}$}} & 56.651 \\
\hline & & & 0.783 \\
\hline \multirow{2}{*}{\multicolumn{2}{|c|}{ Bartlett's Test of Sphericity }} & Chi Square & 1482.417 \\
\hline & & p Value & 0.000 \\
\hline
\end{tabular}


Table 5 shows the factor analysis results belonging to the scale, where the factor weights are organized from big to small. In order to determine the lower dimension of the scale that forms the research questions, a factor analysis was conducted. In order to define the structure of the factor, a factor analysis of the basic components was conducted with the points gathered from the reactions the 441 participants gave to the scale. In order to test if the set of data was suited for the factor analysis, Kaiser - Meyer - Olkin (KMO) Sample Sufficiency test and Bartlett's Test of Sphericity were conducted. The KMO was determined as 0.78 , above the accepted limit value of 0.70 , while Bartlett's Test of Sphericity was above 0.50 . As 0.05 is considred meaningful in the importance scale, the set of data was considered suited for factor analysis. The KMO factor found demonstrates that the data is suited for analysis. The explanatory ratio of the variance was accepted as 0.50 and above. The questions were analyzed using the basic component method, as well as the Varimax rotation method. The question "The length of television shows bothers me" was the only question that stayed below the factor and thus was taken out of the analyis. In the factor analysis, 3 factors with the value of 1 and above were found. The total explained variation was found to be $56.651 \%$.

\section{Reliability Test}

Before going on to analysis and hypothesis tests regarding the defining values of the variants and the relationship between the variants, a reliability test was conducted of the definite groupings of the questions, according to the results gathered from the factor analysis. The Cronbach's Alpha was used to calculate the internal stability of factors. The reliability coefficient can be seen to be 0.75 . This value meets the criteria of the lower limit of 0,70, foreseen in the literature review (Cronbach, 1990). Thus, it can be conluded that the scale used for the research has internal stability.

\section{Analysis Results of the Items Forming the Scale}

The normalcy of the remarks belonging to the scale have been analyzed with the help of the SPSS program and with the Kolmogorov-Smirnov Test. The test results are presented in Table 6.

Table 6. Normality Test of Items

\begin{tabular}{|l|c|c|c|}
\hline \multicolumn{1}{|c|}{ Items } & N & $\begin{array}{c}\text { Kolmogorov- } \\
\text { Smirnov } Z\end{array}$ & $\begin{array}{c}\text { Asymp. } \\
\text { Sig. (2- } \\
\text { tailed) }\end{array}$ \\
\hline $\begin{array}{l}\text { 1. I escape from daily life when I watch } \\
\text { television shows. }\end{array}$ & 441 & 4.687 & 0.000 \\
\hline $\begin{array}{l}\text { 2. I am able to see the development of } \\
\text { characters in time as I watch a } \\
\text { television show. }\end{array}$ & 441 & 6.661 & 0.000 \\
\hline $\begin{array}{l}\text { 3. My general cultural knowledge } \\
\text { increases thanks to television shows. }\end{array}$ & 441 & 5.769 & 0.000 \\
\hline $\begin{array}{l}\text { 4. Foreign television shows support the } \\
\text { development of my foreign language } \\
\text { skills. }\end{array}$ & 441 & 5.990 & 0.000 \\
\hline $\begin{array}{l}\text { 5. I follow each episode of a television } \\
\text { show }\end{array}$ & 441 & 6.107 & 0.000 \\
\hline $\begin{array}{l}\text { 6. I follow through to the season finale } \\
\text { of any television show I begin }\end{array}$ & 441 & 4.809 & 0.000 \\
\hline $\begin{array}{l}\text { 7. Dizileri arka arkaya } \\
\text { izlediğimde(tikinmalı izleme) konuya } \\
\text { kolaylıkla odaklanabilirim. }\end{array}$ & 441 & 4.024 & 0.000 \\
\hline $\begin{array}{l}\text { 8. It makes me happy to be in control } \\
\text { when binge wathing. }\end{array}$ & 441 & 5.928 & 0.000 \\
\hline $\begin{array}{l}\text { 9. Thanks to binge watching, I } \\
\text { understand the subjects of the television }\end{array}$ & 441 & 5.115 & 0.000 \\
\hline
\end{tabular}




\begin{tabular}{|l|c|c|c|}
\hline shows more easily. & & & \\
\hline $\begin{array}{l}\text { 10. Instead of waiting weekly for the } \\
\text { new episode of a television show to come } \\
\text { out, I prefer to save them and watch } \\
\text { them all in one go. }\end{array}$ & 441 & 4.826 & 0.000 \\
\hline $\begin{array}{l}\text { 11. Binge watching can sometimes be } \\
\text { tiring. }\end{array}$ & 441 & 4.218 & 0.000 \\
\hline $\begin{array}{l}\text { 12. I get away from daily life when I } \\
\text { watch television shows }\end{array}$ & 441 & 6.548 & 0.000 \\
\hline
\end{tabular}

According to the test results, it can be seen that the scale questions are not distributed normally $(\mathrm{p}<$ $0,05)$. The analysis was conducted using non-parametric techniques. The normalcy of the dimentions belonging to the scale have been analyzed with the help of the SPSS program and with the Kolmogorov-Smirnov Test. The test results are presented in Table 7.

Table 7. Normality test of Dimensions

\begin{tabular}{|l|c|c|c|}
\hline Dimensions & $\boldsymbol{N}$ & $\begin{array}{c}\text { Kolmogorov- } \\
\text { Smirnov } \boldsymbol{Z}\end{array}$ & $\begin{array}{c}\text { Asymp. Sig. (2- } \\
\text { tailed) }\end{array}$ \\
\hline Factor 1 & 441 & 1.505 & 0.022 \\
\hline Factor 2 & 441 & 2.260 & 0.000 \\
\hline Factor 3 & 441 & 3.553 & 0.000 \\
\hline
\end{tabular}

According to the test results, it can be seen that the groups do not show normal distribution, in terms of their scale dimension $(\mathrm{p}<0,05)$. The analysis was conducted using non-parametric techniques.

Table 8 shows the basic illustrative findings calculated according to the scale used in data collection regarding the items. When the values regarding the items on the scale of the 441 participants are examined, it can be seen that the highest average are of items 7 and 11, that is; "I watch the episodes of a television show one after the other (binge watching) once the season is over." and "Instead of waiting weekly for the new episode of a television show to come out, I prefer to save them and watch them all in one go". After these, the first item "I escape real life when I watch television shows" can be placed. The item which has the lowest average is the fourth one, being "Foreign television shows help the development of my foreign language skills" and the second item, being "I am able to see the development of characters in time as I watch a television show."

Table 8. Descriptive Findings Regarding the Scale $(\mathrm{N}=441)$

\begin{tabular}{|l|c|c|c|c|}
\hline \multicolumn{1}{|c|}{ Items } & Min. & $\begin{array}{c}\text { Ma } \\
\boldsymbol{x} .\end{array}$ & Average & $\begin{array}{c}\text { Stand } \\
\text { art } \\
\text { Deviat } \\
\text { ion }\end{array}$ \\
\hline 1. I escape real life when I watch television shows & 1 & 5 & 3.00 & 1.23 \\
\hline $\begin{array}{l}\text { 2. I am able to see the development of characters in } \\
\text { time as I watch a television show. }\end{array}$ & 1 & 5 & 2.11 & 0.87 \\
\hline $\begin{array}{l}\text { 3. My general cultural knowledge increases thanks to } \\
\text { television shows. }\end{array}$ & 1 & 5 & 2.53 & 0.98 \\
\hline $\begin{array}{l}\text { 4. Foreign television shows help the development of my } \\
\text { foreign language skills. }\end{array}$ & 1 & 5 & 1.86 & 0.87 \\
\hline 5. I follow each episode of television shows. & 1 & 5 & 2.17 & 1.05 \\
\hline $\begin{array}{l}\text { 6. I follow through until the season finale of any } \\
\text { television show I begin to watch. }\end{array}$ & 1 & 5 & 2.40 & 1.09 \\
\hline $\begin{array}{l}\text { 7. I watch the episodes of a television show one after the } \\
\text { other (binge watching) once the season is over. }\end{array}$ & 1 & 5 & 3.02 & 1.19 \\
\hline
\end{tabular}




\begin{tabular}{|l|l|l|l|l|}
\hline $\begin{array}{l}\text { 8. When I watch the episodes of a television show one after } \\
\text { the other (binge watching), I can concentrate on the topic } \\
\text { more easily. }\end{array}$ & 1 & 5 & 2.36 & 1.09 \\
\hline $\begin{array}{l}\text { 9. When I binge watch a show, I feel like I have control } \\
\text { and this makes me happy. }\end{array}$ & 1 & 5 & 2.31 & 1.11 \\
\hline $\begin{array}{l}\text { 10.Thanks to binge watching, I understand the subjects } \\
\text { of the television shows more easily. }\end{array}$ & 1 & 5 & 2.63 & 1.08 \\
\hline $\begin{array}{l}\text { 11.Instead of waiting weekly for the new episode of a } \\
\text { television show to come out, I prefer to save them and } \\
\text { watch them all in one go. }\end{array}$ & 1 & 5 & 3.02 & 1.21 \\
\hline 12. Binge watching can sometimes be tiring. & 1 & 5 & 2.28 & 1.06 \\
\hline
\end{tabular}

Table 9 shows the frequency and percentage distribution of of the answers given to the items on the scale by the 441 participants. $54.9 \%$ of the participants agreed with the statement "I am able to see the development of characters in time as I watch a television show", while $32.7 \%$ of participants disagreed with the statement "I escape real life when I watch television shows".

Table 9. Findings belonging to the Scale ( $\mathrm{N}=441)$

\begin{tabular}{|c|c|c|c|c|c|c|c|c|c|c|}
\hline \multirow[t]{2}{*}{ Items } & \multicolumn{2}{|c|}{$\begin{array}{l}\text { Strongly } \\
\text { Agree }\end{array}$} & \multicolumn{2}{|c|}{$\begin{array}{l}\text { Somewhat } \\
\text { Agree }\end{array}$} & \multicolumn{2}{|c|}{$\begin{array}{c}\text { Neither } \\
\text { Agree } \\
\text { nor } \\
\text { Disagree }\end{array}$} & \multicolumn{2}{|c|}{$\begin{array}{l}\text { Somewhat } \\
\text { disagree }\end{array}$} & \multicolumn{2}{|c|}{$\begin{array}{l}\text { Strongly } \\
\text { Disagree }\end{array}$} \\
\hline & $N$ & $\%$ & $N$ & $\%$ & $N$ & $\%$ & $N$ & $\%$ & $N$ & $\%$ \\
\hline $\begin{array}{l}\text { 1. I escape real life when I } \\
\text { watch television shows }\end{array}$ & 52 & 11.8 & 133 & 30.2 & 65 & $\begin{array}{c}14 . \\
7 \\
\end{array}$ & $\begin{array}{c}14 \\
4\end{array}$ & 32.7 & 47 & 10.7 \\
\hline $\begin{array}{l}\text { 2. I am able to see the } \\
\text { development of characters } \\
\text { in time as I watch a } \\
\text { television show. }\end{array}$ & 96 & 21.8 & 242 & 54.9 & 68 & $\begin{array}{c}15 . \\
4\end{array}$ & 28 & 6.3 & 7 & 1.6 \\
\hline $\begin{array}{l}\text { 3. My general cultural } \\
\text { knowledge increases } \\
\text { thanks to television } \\
\text { shows. } \\
\end{array}$ & 51 & 11.6 & 200 & 45.4 & $\begin{array}{c}10 \\
6\end{array}$ & $\begin{array}{c}24 . \\
0\end{array}$ & 72 & 16.3 & 12 & 2.7 \\
\hline $\begin{array}{l}\text { 4. Foreign television shows } \\
\text { help the development of my } \\
\text { foreign language skills. }\end{array}$ & $\begin{array}{c}16 \\
3\end{array}$ & 37.0 & 212 & 48.1 & 38 & 8.6 & 22 & 5.0 & 6 & 1.4 \\
\hline $\begin{array}{l}\text { 5. I follow each episode of } \\
\text { television shows. }\end{array}$ & $\begin{array}{c}12 \\
5\end{array}$ & 28.3 & 196 & 44.4 & 53 & $\begin{array}{c}12 . \\
0\end{array}$ & 55 & 12.5 & 12 & 2.7 \\
\hline $\begin{array}{l}\text { 6. I follow through until } \\
\text { the season finale of any } \\
\text { television show I begin to } \\
\text { watch. }\end{array}$ & $\begin{array}{c}10 \\
2\end{array}$ & 23.1 & 157 & 35.6 & $\begin{array}{c}10 \\
1\end{array}$ & $\begin{array}{c}22 . \\
9\end{array}$ & 66 & 15.0 & 15 & 3.4 \\
\hline $\begin{array}{l}\text { 7. I watch the episodes of a } \\
\text { television show one after the } \\
\text { other (binge watching) once } \\
\text { the season is over. }\end{array}$ & 47 & 10.7 & 122 & 27.7 & 97 & $\begin{array}{c}22 . \\
0\end{array}$ & $\begin{array}{c}12 \\
7\end{array}$ & 28.8 & 48 & 10.9 \\
\hline $\begin{array}{l}\text { 8. When I watch the } \\
\text { episodes of a television show } \\
\text { one after the other (binge } \\
\text { watching), I can concentrate } \\
\text { on the topic more easily. }\end{array}$ & 91 & 20.6 & 197 & 44.7 & 80 & $\begin{array}{c}18 . \\
1\end{array}$ & 49 & 11.1 & 24 & 5.4 \\
\hline $\begin{array}{l}\text { 9. When I binge watch a } \\
\text { show, I feel like I have }\end{array}$ & $\begin{array}{c}11 \\
9\end{array}$ & 27.0 & 161 & 36.5 & 82 & $\begin{array}{c}18 . \\
6\end{array}$ & 64 & 14.5 & 15 & 3.4 \\
\hline
\end{tabular}




\begin{tabular}{|l|l|l|l|l|l|l|l|l|l|l|}
\hline $\begin{array}{l}\text { control and this makes me } \\
\text { happy. }\end{array}$ & & & & & & & & & & \\
\hline $\begin{array}{l}\text { 10.Thanks to binge } \\
\text { watching, I understand the } \\
\text { subjects of the television } \\
\text { shows more easily. }\end{array}$ & 62 & 14.1 & 163 & 37.0 & $\begin{array}{c}11 \\
3\end{array}$ & $\begin{array}{c}25 . \\
6\end{array}$ & 82 & 18.6 & 21 & 4.8 \\
\hline $\begin{array}{l}\text { 11.Instead of waiting } \\
\text { weekly for the new episode } \\
\text { of a television show to come } \\
\text { out, I prefer to save them } \\
\text { and watch them all in one } \\
\text { go. }\end{array}$ & 61 & 13.8 & 96 & 21.8 & $\begin{array}{c}10 \\
3\end{array}$ & $\begin{array}{c}23 . \\
4\end{array}$ & $\begin{array}{c}13 \\
7\end{array}$ & 31.1 & 44 & 10.0 \\
\hline $\begin{array}{l}\text { 12.Binge watching can } \\
\text { sometimes be tiring. }\end{array}$ & 94 & 21.3 & 218 & 49.4 & 61 & $\begin{array}{c}13 . \\
8\end{array}$ & 47 & 10.7 & 21 & 4.8 \\
\hline
\end{tabular}

\section{Discrepancy Analysis of gathered Data}

\section{Researching Discrepancies of Dimensions According to Gender}

The relationship between the scale dimensions and gender is analyzed according to the Mann Whitney U Test. Table 10 lists the analysis results.

Table 10. Discrepancy Analysis of Dimensions according to Gender $(\mathrm{N}=441)$

\begin{tabular}{|c|c|c|c|c|c|c|c|}
\hline & Gender & $\mathbf{N}$ & M.R. & S. R. & $\mathbf{U}$ & $\mathbf{z}$ & p \\
\hline \multirow{2}{*}{$\begin{array}{l}\text { Factor } \\
1\end{array}$} & Male & 190 & 198.81 & 37773.50 & \multirow{2}{*}{19628.500} & & \multirow{2}{*}{0.001} \\
\hline & Female & 251 & 237.80 & 59687.50 & & 3.190 & \\
\hline \multirow{2}{*}{$\begin{array}{l}\text { Factor } \\
2\end{array}$} & & & & & \multirow[b]{2}{*}{17551.000} & & \multirow[b]{2}{*}{0.000} \\
\hline & $\begin{array}{l}\text { Male } \\
\text { Female }\end{array}$ & $\frac{190}{251}$ & $\frac{18 \% .87}{24608}$ & $\frac{35696.00}{6176500}$ & & - & \\
\hline & & & & & & & \\
\hline \multirow{2}{*}{$\begin{array}{l}\text { Factor } \\
3\end{array}$} & Male & 190 & 208.06 & 39531.50 & \multirow{2}{*}{21386.500} & & \multirow{2}{*}{0.059} \\
\hline & Female & 251 & 230.79 & 57929.50 & & 1.888 & \\
\hline
\end{tabular}

M.R.: Mean Rank

S.R.: Sum of Ranks

As can be seen in Table 10, the variables Factor 1 and Factor 2 demonstrate a statistically significant discrepancy according to gender $(\mathrm{p}<0.05)$. In both dimensions, the answer coming from female participants are more positive than the answers coming from male participants. In contrast, the variable Factor 3 does not demonstrate a statistically significant discrepancy according to gender $(\mathrm{p}>0.05)$.

\section{Researching Discrepancies in Answers According to Gender}

The relationship between the scale dimensions and gender groups is analyzed according to the Mann Whitney U Test. Table 11 lists the analysis results.

Table 11. Disrepancy Analysis of Items According to Gender ( $N=441)$

\begin{tabular}{|c|c|c|c|c|c|c|c|}
\hline & Gender & $\mathbf{N}$ & M.R. & S.R. & $\mathbf{U}$ & $\mathbf{z}$ & p \\
\hline \multirow{2}{*}{$\begin{array}{l}\text { 1. I escape daily life when } \\
\text { I watch television shows }\end{array}$} & Male & 190 & 211.16 & 40119.50 & \multirow{2}{*}{21974.500} & \multirow{2}{*}{$\begin{array}{c}- \\
1.462\end{array}$} & \multirow{2}{*}{0.144} \\
\hline & Female & 251 & 228.45 & 57341.50 & & & \\
\hline 2. I am able to see the & Male & 190 & 211.89 & 40259.50 & 22114.500 & - & 0.149 \\
\hline
\end{tabular}




\begin{tabular}{|c|c|c|c|c|c|c|c|}
\hline $\begin{array}{l}\text { development of } \\
\text { characters in time as I } \\
\text { watch a television show. }\end{array}$ & Female & 251 & 227.89 & 57201.50 & & 1.441 & \\
\hline \multirow{2}{*}{$\begin{array}{l}\text { 3. My general cultural } \\
\text { knowledge increases } \\
\text { thanks to television shows }\end{array}$} & Male & 190 & 189.08 & 35925.00 & \multirow[b]{2}{*}{17780.000} & \multirow[b]{2}{*}{4.859} & \multirow[b]{2}{*}{0.000} \\
\hline & Female & 251 & 245.16 & 61536.00 & & & \\
\hline \multirow{2}{*}{$\begin{array}{l}\text { 4. Foreign television } \\
\text { shows help the } \\
\text { development of my } \\
\text { foreign language skills }\end{array}$} & Male & 190 & 211.87 & 40255.50 & \multirow[b]{2}{*}{22110.500} & \multirow[b]{2}{*}{$1 . \overline{430}$} & \multirow[b]{2}{*}{0.153} \\
\hline & Female & 251 & 227.91 & 57205.50 & & & \\
\hline \multirow{2}{*}{$\begin{array}{l}\text { 5. I follow each episode of } \\
\text { television shows }\end{array}$} & Male & 190 & 198.25 & 37667.00 & \multirow{2}{*}{19522.000} & & \multirow{2}{*}{0.001} \\
\hline & Female & 251 & 238.22 & 59794.00 & & 3.466 & \\
\hline \multirow{2}{*}{$\begin{array}{l}\text { 6. I follow through until } \\
\text { the season finale of any } \\
\text { television show I begin to } \\
\text { watch } \\
\end{array}$} & Male & 190 & 191.32 & 36350.50 & \multirow[b]{2}{*}{18205.500} & \multirow[b]{2}{*}{$4 . \overline{4}$} & \multirow[b]{2}{*}{0.000} \\
\hline & Female & 251 & 243.47 & 61110.50 & & & \\
\hline \multirow{2}{*}{$\begin{array}{l}\text { 7. I binge watch television } \\
\text { shows once the season is } \\
\text { over. }\end{array}$} & Male & 190 & 199.43 & 37891.50 & \multirow[b]{2}{*}{19746.500} & \multirow[b]{2}{*}{$3 . \overline{186}$} & \multirow[b]{2}{*}{0.001} \\
\hline & Female & 251 & 237.33 & 59569.50 & & & \\
\hline \multirow{2}{*}{$\begin{array}{l}\text { 8. When I binge watch a } \\
\text { television show, I focus on } \\
\text { the topic of the show } \\
\text { more easily. }\end{array}$} & Male & 190 & 198.94 & 37798.50 & \multirow[b]{2}{*}{19653.500} & \multirow[b]{2}{*}{3.344} & \multirow[b]{2}{*}{0.001} \\
\hline & Female & 251 & 237.70 & 59662.50 & & & \\
\hline \multirow{2}{*}{$\begin{array}{l}\text { 9. When I binge watch a } \\
\text { show, I feel like I have } \\
\text { control and this makes } \\
\text { me happy. }\end{array}$} & Male & 190 & 203.57 & 38678.00 & \multirow[b]{2}{*}{20533.000} & \multirow[b]{2}{*}{$\begin{array}{c}- \\
2.602\end{array}$} & \multirow[b]{2}{*}{0.009} \\
\hline & Female & 251 & 234.20 & 58783.00 & & & \\
\hline \multirow[b]{2}{*}{$\begin{array}{l}\text { 10. Thanks to binge } \\
\text { watching, I understand } \\
\text { the subjects of the } \\
\text { television shows more } \\
\text { easily. }\end{array}$} & Male & 190 & 204.47 & 38848.50 & \multirow[b]{2}{*}{20703.500} & \multirow[b]{2}{*}{2.467} & \multirow[b]{2}{*}{0.014} \\
\hline & Female & 251 & 233.52 & 58612.50 & & & \\
\hline \multirow{2}{*}{$\begin{array}{l}\text { 11. Instead of waiting } \\
\text { weekly for the new } \\
\text { episode of a television } \\
\text { show to come out, I prefer } \\
\text { to save them and watch } \\
\text { them all in one go. }\end{array}$} & Male & 190 & 207.00 & 39329.50 & \multirow[b]{2}{*}{21184.500} & \multirow[b]{2}{*}{$\begin{array}{c}- \\
2.067\end{array}$} & \multirow[b]{2}{*}{0.039} \\
\hline & Female & 251 & 231.60 & 58131.50 & & & \\
\hline 13. Binge watching can & Male & 190 & 210.14 & 39926.50 & & & \\
\hline sometimes be tiring. & Female & 251 & 229.22 & 57534.50 & 21781.500 & 1.673 & 0.094 \\
\hline
\end{tabular}

M.R.: Mean Rank

S.R.: Sum of Ranks 
According to the analysis results of Table 11, Items 3, 5, 6, 7, 8, 9, 10 and 11 demonstrate a statistically significant discrepancy according to gender $(\mathrm{p}<0.05)$. It can be determined that the female participants' remarks are more positive than the remarks of male participants.

\section{Researching Discrepancies of Dimensions According to Age}

The relationship between the scale dimensions and age groups is analyzed according to the Kruskal Wallis Test. Table 12 lists the analysis results.

Table 12. Discrepancy Analysis of Dimensions according to Age Groups ( $\mathrm{N}=441$ )

\begin{tabular}{|c|c|c|c|c|c|c|}
\hline Dimensions & Age Groups & $N$ & Mean Rank & $\begin{array}{c}\text { Chi- } \\
\text { Square }\end{array}$ & $\begin{array}{l}\text { Standard } \\
\text { Deviation } \\
\end{array}$ & p Value \\
\hline \multirow{6}{*}{ Factor 1} & $13-18$ & 16 & 186.69 & \multirow{5}{*}{7.432} & \multirow{5}{*}{4} & \multirow{5}{*}{0.115} \\
\hline & $19-24$ & 177 & 234.09 & & & \\
\hline & $25-30$ & 107 & 224.84 & & & \\
\hline & $31-36$ & 85 & 192.64 & & & \\
\hline & 37 ve üzeri & 56 & 225.14 & & & \\
\hline & Toplam & 441 & & & & \\
\hline & & & & & & \\
\hline \multirow{6}{*}{ Factor 2} & $13-18$ & 16 & 202.19 & \multirow{5}{*}{22.276} & \multirow{5}{*}{4} & \multirow{5}{*}{0.000} \\
\hline & $19-24$ & 177 & 190.53 & & & \\
\hline & $25-30$ & 107 & 226.63 & & & \\
\hline & $31-36$ & 85 & 259.07 & & & \\
\hline & 37 ve üzeri & 56 & 254.14 & & & \\
\hline & Toplam & 441 & & & & \\
\hline & & & & & & \\
\hline \multirow{6}{*}{ Factor 3} & $13-18$ & 16 & 211.31 & \multirow{5}{*}{21.682} & \multirow{5}{*}{4} & \multirow{5}{*}{0.000} \\
\hline & $19-24$ & 177 & 251.24 & & & \\
\hline & $25-30$ & 107 & 201.50 & & & \\
\hline & $31-36$ & 85 & 216.68 & & & \\
\hline & 37 ve üzeri & 56 & 172.01 & & & \\
\hline & Toplam & 441 & & & & \\
\hline
\end{tabular}

According to the analysis results, the variables Factor 2 and Factor 3 demonstrate a statistically significant discrepancy according to age $(\mathrm{p}<0.05)$. According to the variable Factor 2 , the remarks made by people in the age group 31-36 are more positive than the remarks given in other age groups. According to the variable factor 3, the remarks made by people in the age group 19-24 are more positive than the remarks given in other age groups. In contrast, the Variable factor 1 does not demonstrate a statistically significant discrepancy according to age groups $(\mathrm{p}>0.05)$.

\section{Researching Discrepancies in Items According to Age}

The relationship between the scale items and age groups is analyzed according to the Kruskal Wallis Test. Table 13 lists the analysis results. 
Table 13. Discrepancy Analysis of Items according to Age Groups (N=441)

\begin{tabular}{|c|c|c|c|c|c|c|}
\hline Items & $\begin{array}{c}\text { Age } \\
\text { Groups }\end{array}$ & $N$ & Mean Rank & $\begin{array}{c}\text { Chi- } \\
\text { Square }\end{array}$ & $\begin{array}{c}\text { Standard } \\
\text { Deviation }\end{array}$ & $p$ Value \\
\hline \multirow{6}{*}{$\begin{array}{l}\text { 1. I escape daily } \\
\text { life when I watch } \\
\text { television shows. }\end{array}$} & $13-18$ & 16 & 188.28 & \multirow{5}{*}{20.348} & \multirow{5}{*}{4} & \multirow{5}{*}{0.000} \\
\hline & $19-24$ & 177 & 251.28 & & & \\
\hline & $25-30$ & 107 & 211.57 & & & \\
\hline & $31-36$ & 85 & 202.27 & & & \\
\hline & $\begin{array}{l}37 \text { and } \\
\text { above }\end{array}$ & 56 & 181.09 & & & \\
\hline & Total & 441 & & & & \\
\hline & & & & & & \\
\hline \multirow{6}{*}{$\begin{array}{l}\text { 2. I notice the } \\
\text { developments in } \\
\text { characters over } \\
\text { time when I } \\
\text { watch a telvision } \\
\text { show. }\end{array}$} & $13-18$ & 16 & 236.78 & \multirow{5}{*}{18.097} & \multirow{5}{*}{4} & \multirow{5}{*}{0.001} \\
\hline & $19-24$ & 177 & 196.33 & & & \\
\hline & $25-30$ & 107 & 221.05 & & & \\
\hline & $31-36$ & 85 & 256.90 & & & \\
\hline & $\begin{array}{l}37 \text { and } \\
\text { above }\end{array}$ & 56 & 239.88 & & & \\
\hline & Total & 441 & & & & \\
\hline & & & & & & \\
\hline \multirow{6}{*}{$\begin{array}{l}\text { 3. My cultural } \\
\text { kmowledge } \\
\text { increases when I } \\
\text { watch television } \\
\text { shows. }\end{array}$} & $13-18$ & 16 & 131.75 & \multirow{5}{*}{33.532} & \multirow{5}{*}{4} & \multirow{5}{*}{0.000} \\
\hline & $19-24$ & 177 & 197.40 & & & \\
\hline & $25-30$ & 107 & 217.64 & & & \\
\hline & $31-36$ & 85 & 259.20 & & & \\
\hline & $\begin{array}{l}37 \text { and } \\
\text { above }\end{array}$ & 56 & 269.52 & & & \\
\hline & Total & 441 & & & & \\
\hline & & & & & & \\
\hline \multirow{6}{*}{$\begin{array}{l}\text { 4. Foreign } \\
\text { television shows } \\
\text { help the } \\
\text { development of } \\
\text { my foreign } \\
\text { language skills. }\end{array}$} & $13-18$ & 16 & 276.16 & \multirow{5}{*}{9.414} & \multirow{5}{*}{4} & \multirow{5}{*}{0.052} \\
\hline & $19-24$ & 177 & 206.22 & & & \\
\hline & $25-30$ & 107 & 215.76 & & & \\
\hline & $31-36$ & 85 & 235.69 & & & \\
\hline & $\begin{array}{l}37 \text { and } \\
\text { above }\end{array}$ & 56 & 239.65 & & & \\
\hline & Total & 441 & & & & \\
\hline & & & & & & \multirow{6}{*}{0.013} \\
\hline \multirow{6}{*}{$\begin{array}{l}\text { 5. I follow each } \\
\text { episode of } \\
\text { television shows }\end{array}$} & 13-18 & 16 & 206.72 & \multirow{5}{*}{12.682} & \multirow{5}{*}{4} & \\
\hline & $19-24$ & 177 & 203.84 & & & \\
\hline & $25-30$ & 107 & 213.48 & & & \\
\hline & $31-36$ & 85 & 253.91 & & & \\
\hline & $\begin{array}{l}37 \text { and } \\
\text { above }\end{array}$ & 56 & 243.75 & & & \\
\hline & Total & 441 & & & & \\
\hline \multirow{5}{*}{$\begin{array}{l}\text { 6. I follow } \\
\text { through until the } \\
\text { season finale of } \\
\text { any television } \\
\text { show I begin to } \\
\text { watch. }\end{array}$} & $13-18$ & 16 & 164.69 & \multirow{5}{*}{14.912} & \multirow{5}{*}{4} & \multirow{5}{*}{0.005} \\
\hline & $19-24$ & 177 & 203.04 & & & \\
\hline & $25-30$ & 107 & 252.69 & & & \\
\hline & $31-36$ & 85 & 220.64 & & & \\
\hline & $\begin{array}{l}37 \text { and } \\
\text { above }\end{array}$ & 56 & 233.87 & & & \\
\hline
\end{tabular}




\begin{tabular}{|c|c|c|c|c|c|c|}
\hline & Total & 441 & & & & \\
\hline \multirow{6}{*}{$\begin{array}{l}\text { 7. I watch the } \\
\text { episodes of a } \\
\text { television show } \\
\text { one after the other } \\
\text { (binge watching) } \\
\text { once the season is } \\
\text { over. }\end{array}$} & $13-18$ & 16 & 133.44 & \multirow{5}{*}{13.574} & \multirow{5}{*}{4} & \multirow{5}{*}{0.009} \\
\hline & $19-24$ & 177 & 233.25 & & & \\
\hline & $25-30$ & 107 & 215.83 & & & \\
\hline & $31-36$ & 85 & 203.41 & & & \\
\hline & $\begin{array}{l}37 \text { and } \\
\text { above }\end{array}$ & 56 & 243.86 & & & \\
\hline & Total & 441 & & & & \\
\hline \multirow{6}{*}{$\begin{array}{l}\text { 8. When I watch } \\
\text { the episodes of a } \\
\text { television show } \\
\text { one after the other } \\
\text { (binge watching), I } \\
\text { can concentrate on } \\
\text { the topic more } \\
\text { easily. }\end{array}$} & & & & \multirow{5}{*}{2.321} & \multirow{5}{*}{4} & \multirow{5}{*}{0.677} \\
\hline & $\frac{15-10}{1024}$ & 10 & $\frac{219.01}{23138}$ & & & \\
\hline & $25-30$ & 107 & 211.05 & & & \\
\hline & $31-36$ & 85 & 215.05 & & & \\
\hline & $\begin{array}{l}37 \text { and } \\
\text { above }\end{array}$ & 56 & 216.72 & & & \\
\hline & Total & 441 & & & & \\
\hline \multirow{7}{*}{$\begin{array}{l}\text { 9. When I binge } \\
\text { watch a show, I } \\
\text { feel like I have } \\
\text { control and this } \\
\text { makes me happy. }\end{array}$} & & & & \multirow{6}{*}{1.056} & & \\
\hline & $13-18$ & 16 & 219.69 & & \multirow{5}{*}{4} & \multirow{5}{*}{0.901} \\
\hline & $19-24$ & 177 & 224.19 & & & \\
\hline & $25-30$ & 107 & 219.50 & & & \\
\hline & $31-36$ & 85 & 210.58 & & & \\
\hline & $\begin{array}{l}37 \text { and } \\
\text { above }\end{array}$ & 56 & 229.99 & & & \\
\hline & Total & 441 & & & & \\
\hline \multirow{7}{*}{$\begin{array}{l}\text { 10. Thanks to } \\
\text { binge watching, I } \\
\text { understand the } \\
\text { subjects of the } \\
\text { television shows } \\
\text { more easily. }\end{array}$} & & & & \multirow{6}{*}{0.744} & \multirow{6}{*}{4} & \\
\hline & $13-18$ & 16 & 221.72 & & & \multirow{5}{*}{0.946} \\
\hline & $19-24$ & 177 & 223.85 & & & \\
\hline & $25-30$ & 107 & 225.64 & & & \\
\hline & $31-36$ & 85 & 213.01 & & & \\
\hline & $\begin{array}{l}37 \text { and } \\
\text { above }\end{array}$ & 56 & 215.06 & & & \\
\hline & Total & 441 & & & & \\
\hline \multirow{6}{*}{$\begin{array}{l}\text { 11. Instead of } \\
\text { waiting weekly } \\
\text { for the new } \\
\text { episode of a } \\
\text { television show to } \\
\text { come out, I prefer } \\
\text { to save them and } \\
\text { watch them all in } \\
\text { one go. }\end{array}$} & $13-18$ & 16 & 185.31 & \multirow{5}{*}{18.236} & \multirow{5}{*}{4} & \multirow{5}{*}{0.001} \\
\hline & $19-24$ & 177 & 231.14 & & & \\
\hline & $25-30$ & 107 & 245.17 & & & \\
\hline & $31-36$ & 85 & 175.21 & & & \\
\hline & $\begin{array}{l}37 \text { and } \\
\text { above }\end{array}$ & 56 & 222.46 & & & \\
\hline & Total & 441 & & & & \\
\hline 12. Binge & $13-18$ & 16 & 246.59 & 19.132 & 4 & 0.001 \\
\hline
\end{tabular}




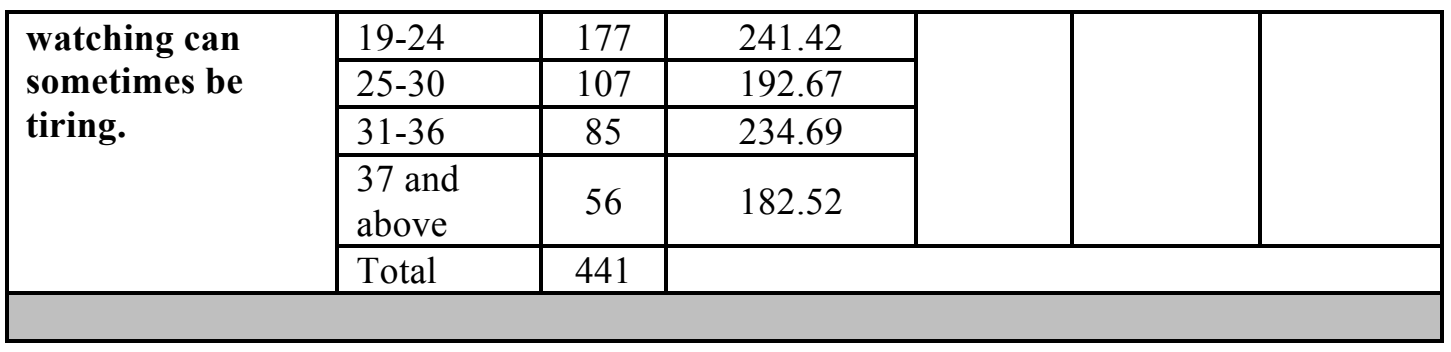

According to the results in Table 12 , items $1,2,3,5,6,7,11$ and 12 demonstrate a statistically significant discrepancy according to age groups $(p<0.05)$. In contrast, Items $4,8,7,9$ and 10 do not demonstrate a statistically significant discrepancy according to age groups $(\mathrm{p}>0.05)$.

\section{Researching Discrepancies in Dimensions according to Educational Level}

The relationship between the scale dimensions and the educational level is analyzed according to the Kruskal Wallis Test. Table 14 lists the analysis results.

Table 14. Discrepancy Analysis of Dimensions according to Educational Level (N=441)

\begin{tabular}{|c|c|c|c|c|c|c|}
\hline Dimensions & $\begin{array}{c}\text { Educational } \\
\text { Level }\end{array}$ & $N$ & Mean Rank & $\begin{array}{c}\text { Chi- } \\
\text { Square }\end{array}$ & $\begin{array}{l}\text { Standard } \\
\text { Deviation }\end{array}$ & p Value \\
\hline \multirow{7}{*}{ Factor 1} & Primary School & 2 & 384.75 & \multirow{6}{*}{5.613} & \multirow{6}{*}{5} & \multirow{6}{*}{0.346} \\
\hline & Middle School & 24 & 255.46 & & & \\
\hline & $\begin{array}{l}\text { Vocational } \\
\text { School }\end{array}$ & 17 & 229.76 & & & \\
\hline & $\begin{array}{l}\text { Undergraduate } \\
\text { degree }\end{array}$ & 274 & 218.37 & & & \\
\hline & Master's degree & 83 & 219.55 & & & \\
\hline & Doctoral degree & 41 & 209.73 & & & \\
\hline & Total & 441 & & & & \\
\hline & & & & & & \\
\hline \multirow{7}{*}{ Factor 2} & Primary School & 2 & 217.00 & \multirow{6}{*}{4.856} & \multirow{6}{*}{5} & \multirow{6}{*}{0.434} \\
\hline & Middle School & 24 & 241.10 & & & \\
\hline & $\begin{array}{l}\text { Vocational } \\
\text { School }\end{array}$ & 17 & 204.50 & & & \\
\hline & $\begin{array}{l}\text { Undergraduate } \\
\text { degree }\end{array}$ & 274 & 216.98 & & & \\
\hline & Master's degree & 83 & 242.80 & & & \\
\hline & Doctoral degree & 41 & 199.01 & & & \\
\hline & Total & 441 & & & & \\
\hline & & & & & & \\
\hline \multirow{7}{*}{ Factor 3} & Primary School & 2 & 323.75 & \multirow{6}{*}{2.997} & \multirow{6}{*}{5} & \multirow{6}{*}{0.700} \\
\hline & Middle School & 24 & 242.27 & & & \\
\hline & $\begin{array}{l}\text { Vocational } \\
\text { School }\end{array}$ & 17 & 245.71 & & & \\
\hline & $\begin{array}{l}\text { Undergraduate } \\
\text { degree }\end{array}$ & 274 & 219.40 & & & \\
\hline & Master's degree & 83 & 215.72 & & & \\
\hline & Doctoral degree & 41 & 214.68 & & & \\
\hline & Total & 441 & & & & \\
\hline
\end{tabular}


According to the analysis results, there is no discrepancy in scale dimensions according to the educational level $(\mathrm{p}>0.05)$.

\section{Researching Discrepancies in Items according to the Educational Level}

The relationship between the scale items and the educational level is analyzed according to the Kruskal Wallis Test. Table 15 lists the analysis results.

Table 15.Discrepancy Analysis of Items according to Educational Level ( $\mathrm{N}=441)$

\begin{tabular}{|c|c|c|c|c|c|c|}
\hline Items & $\begin{array}{c}\text { Educational } \\
\text { Level }\end{array}$ & $N$ & Mean Rank & $\begin{array}{l}\text { Chi- } \\
\text { Square }\end{array}$ & $\begin{array}{l}\text { Standard } \\
\text { Deviation } \\
\end{array}$ & $p$ Value \\
\hline \multirow{7}{*}{$\begin{array}{l}\text { 1. I escape } \\
\text { real life when } \\
\text { I watch } \\
\text { television } \\
\text { shows }\end{array}$} & Primary School & 2 & 220.75 & \multirow{6}{*}{4.179} & \multirow{6}{*}{5} & \multirow{6}{*}{0.524} \\
\hline & Middle School & 24 & 236.42 & & & \\
\hline & $\begin{array}{l}\text { Vocational } \\
\text { School }\end{array}$ & 17 & 244.26 & & & \\
\hline & $\begin{array}{l}\text { Undergraduate } \\
\text { degree }\end{array}$ & 274 & 225.94 & & & \\
\hline & Master's degree & 83 & 208.61 & & & \\
\hline & Doctoral degree & 41 & 194.44 & & & \\
\hline & Total & 441 & & & & \\
\hline \multirow{8}{*}{$\begin{array}{l}\text { 2. I am able to } \\
\text { see the } \\
\text { development } \\
\text { of characters } \\
\text { in time as I } \\
\text { watch a } \\
\text { television } \\
\text { show. }\end{array}$} & & & & \multirow{7}{*}{10.693} & \multirow{7}{*}{5} & \multirow{7}{*}{0.058} \\
\hline & Primary School & 2 & 133.00 & & & \\
\hline & Middle School & 24 & 242.94 & & & \\
\hline & $\begin{array}{l}\text { Vocational } \\
\text { School }\end{array}$ & 17 & 237.74 & & & \\
\hline & $\begin{array}{l}\text { Undergraduate } \\
\text { degree }\end{array}$ & 274 & 211.54 & & & \\
\hline & Master's degree & 83 & 251.63 & & & \\
\hline & Doctoral degree & 41 & 206.74 & & & \\
\hline & Total & 441 & & & & \\
\hline & & & & & & \\
\hline \multirow{7}{*}{$\begin{array}{l}\text { 3. My general } \\
\text { cultural } \\
\text { knowledge } \\
\text { increases } \\
\text { thanks to } \\
\text { television } \\
\text { shows. }\end{array}$} & Primary School & 2 & 165.25 & \multirow{6}{*}{2.280} & \multirow{6}{*}{5} & \multirow{6}{*}{0.809} \\
\hline & Middle School & 24 & 217.42 & & & \\
\hline & $\begin{array}{l}\text { Vocational } \\
\text { School }\end{array}$ & 17 & 242.97 & & & \\
\hline & $\begin{array}{l}\text { Undergraduate } \\
\text { degree }\end{array}$ & 274 & 216.05 & & & \\
\hline & Master's degree & 83 & 231.33 & & & \\
\hline & Doctoral degree & 41 & 228.89 & & & \\
\hline & Total & 441 & & & & \\
\hline \multirow{7}{*}{$\begin{array}{l}\text { 4. Foreign } \\
\text { television } \\
\text { shows help } \\
\text { the } \\
\text { development } \\
\text { of my foreign } \\
\text { language } \\
\text { skills. }\end{array}$} & Primary School & 2 & 238.25 & \multirow{6}{*}{5.868} & \multirow{6}{*}{5} & \multirow{6}{*}{0.319} \\
\hline & Middle School & 24 & 262.17 & & & \\
\hline & $\begin{array}{l}\text { Vocational } \\
\text { School }\end{array}$ & 17 & 215.03 & & & \\
\hline & $\begin{array}{l}\text { Undergraduate } \\
\text { degree }\end{array}$ & 274 & 213.56 & & & \\
\hline & Master's degree & 83 & 222.89 & & & \\
\hline & Doctoral degree & 41 & 244.43 & & & \\
\hline & Total & 441 & & & & \\
\hline
\end{tabular}




\begin{tabular}{|c|c|c|c|c|c|c|}
\hline \multirow{7}{*}{$\begin{array}{l}\text { 5. I follow } \\
\text { each episode } \\
\text { of television } \\
\text { shows. }\end{array}$} & Primary School & 2 & 232.50 & \multirow{6}{*}{9.661} & \multirow{6}{*}{5} & \multirow{6}{*}{0.085} \\
\hline & Middle School & 24 & 226.90 & & & \\
\hline & $\begin{array}{l}\text { Vocational } \\
\text { School }\end{array}$ & 17 & 189.88 & & & \\
\hline & $\begin{array}{l}\text { Undergraduate } \\
\text { degree }\end{array}$ & 274 & 216.23 & & & \\
\hline & Master's degree & 83 & 253.70 & & & \\
\hline & Doctoral degree & 41 & 195.60 & & & \\
\hline & Total & 441 & & & & \\
\hline & & & & & & \\
\hline \multirow{7}{*}{$\begin{array}{l}\text { 6. I follow } \\
\text { through until } \\
\text { the season } \\
\text { finale of any } \\
\text { television } \\
\text { show I begin } \\
\text { to watch. }\end{array}$} & Primary School & 2 & 287.25 & \multirow{6}{*}{12.482} & \multirow{6}{*}{5} & \multirow{6}{*}{0.029} \\
\hline & Middle School & 24 & 185.42 & & & \\
\hline & $\begin{array}{l}\text { Vocational } \\
\text { School }\end{array}$ & 17 & 162.94 & & & \\
\hline & $\begin{array}{l}\text { Undergraduate } \\
\text { degree }\end{array}$ & 274 & 229.88 & & & \\
\hline & Master's degree & 83 & 231.34 & & & \\
\hline & Doctoral degree & 41 & 182.41 & & & \\
\hline & Total & 441 & & & & \\
\hline \multirow{8}{*}{$\begin{array}{l}\text { 7. I watch the } \\
\text { episodes of a } \\
\text { television } \\
\text { show one } \\
\text { after the other } \\
\text { (binge } \\
\text { watching) } \\
\text { once the } \\
\text { season is over. }\end{array}$} & & & & \multirow{7}{*}{4.963} & \multirow{7}{*}{5} & \multirow{7}{*}{0.420} \\
\hline & Primary School & 2 & 330.00 & & & \\
\hline & Middle School & 24 & 243.04 & & & \\
\hline & $\begin{array}{l}\text { Vocational } \\
\text { School }\end{array}$ & 17 & 181.26 & & & \\
\hline & $\begin{array}{l}\text { Undergraduate } \\
\text { degree }\end{array}$ & 274 & 221.05 & & & \\
\hline & Master's degree & 83 & 227.67 & & & \\
\hline & Doctoral degree & 41 & 205.41 & & & \\
\hline & Total & 441 & & & & \\
\hline \multirow{7}{*}{$\begin{array}{l}\text { 8. When I } \\
\text { watch the } \\
\text { episodes of a } \\
\text { television } \\
\text { show one } \\
\text { after the other } \\
\text { (binge } \\
\text { watching), I } \\
\text { can } \\
\text { concentrate } \\
\text { on the topic } \\
\text { more easily. }\end{array}$} & Primary School & 2 & 360.75 & \multirow{6}{*}{8.369} & \multirow{6}{*}{5} & \multirow{6}{*}{0.137} \\
\hline & Middle School & 24 & 255.42 & & & \\
\hline & $\begin{array}{l}\text { Vocational } \\
\text { School }\end{array}$ & 17 & 213.88 & & & \\
\hline & $\begin{array}{l}\text { Undergraduate } \\
\text { degree }\end{array}$ & 274 & 218.73 & & & \\
\hline & Master's degree & 83 & 232.30 & & & \\
\hline & Doctoral degree & 41 & 189.28 & & & \\
\hline & Total & 441 & & & & \\
\hline \multirow{8}{*}{$\begin{array}{l}\text { 9. When I } \\
\text { binge watch a } \\
\text { show, I feel } \\
\text { like I have } \\
\text { control and } \\
\text { this makes me } \\
\text { happy. }\end{array}$} & & & & & & \\
\hline & Primary School & 2 & 358.00 & \multirow{6}{*}{5.845} & \multirow{6}{*}{5} & \multirow{6}{*}{0.322} \\
\hline & Middle School & 24 & 257.81 & & & \\
\hline & $\begin{array}{l}\text { Vocational } \\
\text { School }\end{array}$ & 17 & 222.88 & & & \\
\hline & $\begin{array}{l}\text { Undergraduate } \\
\text { degree }\end{array}$ & 274 & 214.12 & & & \\
\hline & Master's degree & 83 & 228.11 & & & \\
\hline & Doctoral degree & 41 & 223.55 & & & \\
\hline & Total & 441 & & & & \\
\hline
\end{tabular}




\begin{tabular}{|c|c|c|c|c|c|c|}
\hline \multirow{7}{*}{$\begin{array}{l}\text { 10. Thanks to } \\
\text { binge } \\
\text { watching, I } \\
\text { understand } \\
\text { the subjects of } \\
\text { the television } \\
\text { shows more } \\
\text { easily. }\end{array}$} & Primary School & 2 & 330.75 & \multirow{6}{*}{8.112} & \multirow{6}{*}{5} & \multirow{6}{*}{0.150} \\
\hline & Middle School & 24 & 271.17 & & & \\
\hline & $\begin{array}{l}\text { Vocational } \\
\text { School }\end{array}$ & 17 & 234.26 & & & \\
\hline & $\begin{array}{l}\text { Undergraduate } \\
\text { degree }\end{array}$ & 274 & 220.74 & & & \\
\hline & Master's degree & 83 & 200.78 & & & \\
\hline & Doctoral degree & 41 & 223.41 & & & \\
\hline & Total & 441 & & & & \\
\hline 11. Instead of & Primary School & 2 & 329.00 & & & \\
\hline waiting & Middle School & 24 & 248.67 & & & \\
\hline $\begin{array}{l}\text { weekly for the } \\
\text { new episode }\end{array}$ & $\begin{array}{l}\text { Vocational } \\
\text { School }\end{array}$ & 17 & 288.68 & & & \\
\hline $\begin{array}{l}\text { of a television } \\
\text { show to come }\end{array}$ & $\begin{array}{l}\begin{array}{l}\text { Undergraduate } \\
\text { degree }\end{array} \\
\end{array}$ & 274 & 215.24 & 8.912 & 5 & 0.113 \\
\hline out, I prefer & Master's degree & 83 & 212.37 & & & \\
\hline to save them & Doctoral degree & 41 & 227.46 & & & \\
\hline $\begin{array}{l}\text { them all in } \\
\text { one go. }\end{array}$ & Total & 441 & & & & \\
\hline & & & & & & \\
\hline & Primary School & 2 & 317.25 & & & \\
\hline & Middle School & 24 & 240.88 & & & \\
\hline 12. Binge & $\begin{array}{l}\text { Vocational } \\
\text { School }\end{array}$ & 17 & 251.91 & 4500 & 5 & 0468 \\
\hline $\begin{array}{l}\text { watching can } \\
\text { sometimes be } \\
\text { tiring }\end{array}$ & $\begin{array}{l}\text { Undergraduate } \\
\text { degree }\end{array}$ & 274 & 213.66 & 4.590 & 3 & 0.408 \\
\hline & Master's degree & 83 & 226.75 & & & \\
\hline & Doctoral degree & 41 & 229.26 & & & \\
\hline & Total & 441 & & & & \\
\hline
\end{tabular}

According to the analysis results, the $6^{\text {th }}$ item demonstrates a statistically significant discrepancy according to the educational level. It can be seen that in the elementary school grouping of the $6^{\text {th }}$ item, the remarks made are more positive than other groups.

\section{Researching Disrepancies in Dimensions According to Occupation}

The relationship between the scale dimensions and occupation is analyzed according to the Kruskal Wallis Test. Table 16 lists the analysis results.

Table 16. Discrepancy Analysis of Dimensions According to Occupation ( $\mathrm{N}=441)$

\begin{tabular}{|l|l|c|c|c|c|c|}
\hline Dimensions & Occupation & $N$ & Mean Rank & $\begin{array}{c}\text { Chi- } \\
\text { square }\end{array}$ & $\begin{array}{c}\text { Standard } \\
\text { Deviation }\end{array}$ & $p$ Value \\
\hline \multirow{4}{*}{ Factor 1 } & Payed & 117 & 196.22 & & & \\
\cline { 2 - 5 } & Freelance & 43 & 211.60 & & & \multirow{4}{*}{9.337} \\
\cline { 2 - 4 } & Unemployed & 25 & 269.08 & 4 & 0.053 \\
\cline { 2 - 4 } & Student & 208 & 228.75 & & & \\
\cline { 2 - 4 } & Other & 48 & 231.18 & & & \\
\hline
\end{tabular}




\begin{tabular}{|c|c|c|c|c|c|c|}
\hline & Total & 441 & & & & \\
\hline & & & & & & \\
\hline \multirow{6}{*}{ Factor 2} & Payed & 117 & 260.12 & \multirow{5}{*}{32.091} & \multirow{5}{*}{4} & \multirow{5}{*}{0.000} \\
\hline & Freelance & 43 & 210.37 & & & \\
\hline & Unemployed & 25 & 231.84 & & & \\
\hline & Student & 208 & 188.72 & & & \\
\hline & Other & 48 & 269.38 & & & \\
\hline & Total & 441 & & & & \\
\hline & & & & & & \\
\hline \multirow{6}{*}{ Factor 3} & Payed & 117 & 195.49 & \multirow{5}{*}{12.209} & \multirow{5}{*}{4} & \multirow{5}{*}{0.016} \\
\hline & Freelance & 43 & 223.78 & & & \\
\hline & Unemployed & 25 & 250.00 & & & \\
\hline & Student & 208 & 237.64 & & & \\
\hline & Other & 48 & 193.47 & & & \\
\hline & Total & 441 & & & & \\
\hline
\end{tabular}

According to the analysis results, Factor 2 and 3 demonstrate a statistically significant dicrepancy according to occupation $(\mathrm{p}<0.05)$. According to the variable Factor 2, the remarks made by people in the payed group are more positive than the other groups. According to the variable Factor 3, the remarks of the people in the unemployed group are more positive than the other groups. In contrast, Factor 1 does not demonstrate a statistically significant discrepancy according to occupation ( $>0.05$ ).

\section{Researching Discrepancies of Items According to Occupation}

The relationship between the scale items and occupation is analyzed according to the Kruskal Wallis Test. Table 17 lists the analysis results.

Table 17. Discrepancy Analysis of Items According to Occupation ( $\mathrm{N}=441)$

\begin{tabular}{|c|c|c|c|c|c|c|}
\hline Items & Occupation & $N$ & Mean Rank & $\begin{array}{c}\text { Chi- } \\
\text { Square }\end{array}$ & $\begin{array}{l}\text { Standard } \\
\text { Deviation }\end{array}$ & $p$ Value \\
\hline \multirow{6}{*}{$\begin{array}{l}\text { 1. I escape real } \\
\text { life when I watch } \\
\text { television shows }\end{array}$} & Payed & 117 & 196.83 & \multirow{5}{*}{15.095} & \multirow{5}{*}{4} & \multirow{5}{*}{0.005} \\
\hline & Freelance & 43 & 196.55 & & & \\
\hline & Unemployed & 25 & 268.38 & & & \\
\hline & Student & 208 & 238.23 & & & \\
\hline & Other & 48 & 202.47 & & & \\
\hline & Total & 441 & & & & \\
\hline \multirow{7}{*}{$\begin{array}{l}\text { 2. I am able to } \\
\text { see the } \\
\text { development of } \\
\text { characters in } \\
\text { time as I watch a } \\
\text { television show. }\end{array}$} & & & & \multirow{6}{*}{15.924} & \multirow{6}{*}{4} & \multirow{6}{*}{0.003} \\
\hline & Payed & 117 & 255.64 & & & \\
\hline & Freelance & 43 & 204.29 & & & \\
\hline & Unemployed & 25 & 208.30 & & & \\
\hline & Student & 208 & 204.94 & & & \\
\hline & Other & 48 & 227.75 & & & \\
\hline & Total & 441 & & & & \\
\hline \multirow{6}{*}{$\begin{array}{l}\text { 3. My general } \\
\text { cultural } \\
\text { knowledge } \\
\text { increases thanks } \\
\text { to television } \\
\text { shows. }\end{array}$} & Payed & 117 & 251.04 & \multirow{5}{*}{27.280} & \multirow{5}{*}{4} & \multirow{5}{*}{0.000} \\
\hline & Freelance & 43 & 245.13 & & & \\
\hline & Unemployed & 25 & 249.60 & & & \\
\hline & Student & 208 & 189.45 & & & \\
\hline & Other & 48 & 247.97 & & & \\
\hline & Total & 441 & & & & \\
\hline
\end{tabular}




\begin{tabular}{|c|c|c|c|c|c|c|}
\hline \multirow{6}{*}{$\begin{array}{l}\text { 4. Foreign } \\
\text { television shows } \\
\text { help the } \\
\text { development of } \\
\text { my foreign } \\
\text { language skills. }\end{array}$} & Payed & 117 & 237.60 & \multirow{5}{*}{6.214} & \multirow{5}{*}{4} & \multirow{5}{*}{0.184} \\
\hline & Freelance & 43 & 224.60 & & & \\
\hline & Unemployed & 25 & 202.00 & & & \\
\hline & Student & 208 & 209.25 & & & \\
\hline & Other & 48 & 238.09 & & & \\
\hline & Total & 441 & & & & \\
\hline \multirow{7}{*}{$\begin{array}{l}\text { 5. I follow each } \\
\text { episode of } \\
\text { television shows. }\end{array}$} & & & & \multirow{6}{*}{16.700} & & \\
\hline & Payed & 117 & 239.92 & & \multirow{5}{*}{4} & \multirow{5}{*}{0.002} \\
\hline & Freelance & 43 & 241.67 & & & \\
\hline & Unemployed & 25 & 217.08 & & & \\
\hline & Student & 208 & 197.86 & & & \\
\hline & Other & 48 & 258.70 & & & \\
\hline & Total & 441 & & & & \\
\hline & & & & & & \\
\hline \multirow{6}{*}{$\begin{array}{l}\text { 6. I follow } \\
\text { through until the } \\
\text { season finale of } \\
\text { any television } \\
\text { show I begin to } \\
\text { watch. }\end{array}$} & Payed & 117 & 239.71 & \multirow{5}{*}{24.374} & \multirow{5}{*}{4} & \multirow{5}{*}{0.000} \\
\hline & Freelance & 43 & 211.64 & & & \\
\hline & Unemployed & 25 & 264.38 & & & \\
\hline & Student & 208 & 194.98 & & & \\
\hline & Other & 48 & 273.94 & & & \\
\hline & Total & 441 & & & & \\
\hline \multirow{6}{*}{$\begin{array}{l}\text { 7. I watch the } \\
\text { episodes of a } \\
\text { television show } \\
\text { one after the } \\
\text { other (binge } \\
\text { watching) once } \\
\text { the season is } \\
\text { over. }\end{array}$} & Paved & 117 & 20877 & \multirow{5}{*}{3.957} & & \multirow{5}{*}{0.412} \\
\hline & Freelance & 43 & 213.49 & & \multirow{4}{*}{4} & \\
\hline & Unemployed & 25 & 255.42 & & & \\
\hline & Student & 208 & 221.82 & & & \\
\hline & Other & 48 & 236.04 & & & \\
\hline & Total & 441 & & & & \\
\hline \multirow{7}{*}{$\begin{array}{l}\text { 8. When I watch } \\
\text { the episodes of a } \\
\text { television show } \\
\text { one after the } \\
\text { other (binge } \\
\text { watching), I can } \\
\text { concentrate on } \\
\text { the topic more } \\
\text { easily. }\end{array}$} & & & & & & \\
\hline & Payed & 117 & 194.68 & \multirow{5}{*}{19.581} & \multirow{5}{*}{4} & \multirow{5}{*}{0.001} \\
\hline & Freelance & 43 & 233.19 & & & \\
\hline & Unemployed & 25 & 297.00 & & & \\
\hline & Student & 208 & 216.78 & & & \\
\hline & Other & 48 & 252.95 & & & \\
\hline & Total & 441 & & & & \\
\hline \multirow{6}{*}{$\begin{array}{l}\text { 9. When I binge } \\
\text { watch a show, I } \\
\text { feel like I have } \\
\text { control and this } \\
\text { makes me happy. }\end{array}$} & Payed & 117 & 195.80 & \multirow{5}{*}{10.605} & \multirow{5}{*}{4} & \multirow{5}{*}{0.031} \\
\hline & Freelance & 43 & 220.22 & & & \\
\hline & Unemployed & 25 & 261.00 & & & \\
\hline & Student & 208 & 223.61 & & & \\
\hline & Other & 48 & 250.98 & & & \\
\hline & Total & 441 & & & & \\
\hline 10. Thanks & Payed & 117 & 202.59 & & & \\
\hline to binge & Freelance & 43 & 209.97 & & & \\
\hline watching, I & Unemployed & 25 & 266.06 & 6.989 & 4 & 0.136 \\
\hline understand the & Student & 208 & 227.46 & & & \\
\hline subjects of the & Other & 48 & 224.29 & & & \\
\hline
\end{tabular}




\begin{tabular}{|c|c|c|c|c|c|c|}
\hline $\begin{array}{l}\text { television shows } \\
\text { more easily. }\end{array}$ & Total & 441 & & & & \\
\hline \multirow{6}{*}{$\begin{array}{l}\text { 11. Instead of } \\
\text { waiting weekly } \\
\text { for the new } \\
\text { episode of a } \\
\text { television show } \\
\text { to come out, I } \\
\text { prefer to save } \\
\text { them and watch } \\
\text { them all in one } \\
\text { go. }\end{array}$} & Payed & 117 & 215.29 & \multirow{5}{*}{4.573} & \multirow{5}{*}{4} & \multirow{5}{*}{0.334} \\
\hline & Freelance & 43 & 206.38 & & & \\
\hline & Unemployed & 25 & 206.22 & & & \\
\hline & Student & 208 & 233.57 & & & \\
\hline & Other & 48 & 201.24 & & & \\
\hline & Total & 441 & & & & \\
\hline & & & & & & \\
\hline \multirow{6}{*}{$\begin{array}{l}\text { 12. Binge } \\
\text { watching can } \\
\text { sometimes be } \\
\text { tiring. }\end{array}$} & Payed & 117 & 207.35 & \multirow{5}{*}{8.683} & \multirow{5}{*}{4} & \multirow{5}{*}{0.070} \\
\hline & Freelance & 43 & 255.83 & & & \\
\hline & Unemployed & 25 & 211.72 & & & \\
\hline & Student & 208 & 228.72 & & & \\
\hline & Other & 48 & 194.61 & & & \\
\hline & Total & 441 & & & & \\
\hline
\end{tabular}

According to the analysis results of Table 17; items 1, 2, 3, 5, 6, 8 and 9 do not show significant discrepancy according to occupation $(\mathrm{p}<0.05)$. In contrast, items $4,7,10,11$ and 12 show significant discrepancy according to occupation ( $\mathrm{p}>0.05)$.

\section{RESEARCH FINDINGS}

It can be concluded according to the research findings that television show viewers are aware of what "binge watching" is and use this practice of viewing. The characteristics provided by the media such as easement, information, complementary servising, affirmation and reiforment of social experience mentioned in the uses and gratification theory can also be seen in the research findings. Media is used for things such as escaping daily life, expanding general cultural knowledge, and personal growth. Watching television shows as a popular culture actvity is a form of continuity of sharing with a community. With the use of new media, viewing habits are changing, and as a result of this change, binge watching as a new habit is embraced by viewers. Instead of waiting for a new episode to come out every week, it has become more popular to accumulate the episodes and watch them in one go at a decided time. Binge watching allows viewer to be more in control of their viewing experience, concentrate more easily on the topic of the television show and finish the episodes in one go. While this habit is a tiresome one, it is a popular one nonetheless and has led to the rise of a new sector. In this context, companies that provide IPTV services (Netflix, Amazon, Apple TV) have begun producing their own shows.

This new way of watching television shows has settled as a practice in the American industry. There is no doubt that it will makes its way to Turkey and complicate traditional television broadcast. Companies such as Netflix in the United States and their extension in Turkey, such as TVYO and Tivibu will no doubt become more and more widespread as platforms. In light of this new viewing practice, it is believed that interest in television shows will increase, while interest in films will decrease.

\section{CONCLUSIONS}

Ways of socializing are changing with the advent of new media. Individuals satisfy their needs through this environment and thus the space of traditional media alters to the digital. Individuals can 
now socializing from where they are seated. Individuals use what is digital in order to be social. In order to be social, individuals now use the digital. It can be seen that today, individuals not only have an interactive relationship with new media, which can also be called social media, but also become addicted to it, by their own wills (Güngör, 2013:125).

Amusement has become an extension of labor under late capitalism. It is sought after as an escape from the mechanized work process and to recruit strength in order to be able to cope with it again. But at the same time, mechanization has such a power over man's leisure and happiness and so profoundly determines the manufacture of amusement goods, that his experiences are inevitable after-images of the work process itself. Pleasure always means not to think about anything, to forget suffering even where it is shown. Basically it is helplessness. It is flight ... from the last remaining thought of resistance'. (Adorno, 2012:16-21).

According to Kellner, the merging of entertainment technologies with corporate capitalism and education has shaped new social and cultural forms that are controlled by capital and global access. In this context, in a society defined through networks of education and entertainment, the technocapitalist developments in cabled and cableless multimedia and entertainment/education technologies underline how close education and entertainment are to one another (Kellner, 2010:43). According to Oskay, along with modern communication technology, instead of a united mass of people, the production of a dissipated mass has come about, where people themselves have been forced to join in on the very production that puts them in the position of unpayed workers.

It may seem that people who lock themselves in their home are refusing the outside world; in a way this is true. They watch, without missing a second, the phantom world unrolling on their screens, where, instead of being a product of the world they live in, they become the products of the image world, not living in a world that belongs to them. Their business life is left unaffected by this activity, which is relegated to the free time. As a matter of fact, contemporary man pays with his own money for the very lack of freedom that turns him into just another member of mass society (Oskay, 2000:11). The routine and standardisation of working hours after the industrial revolution has led new technologies and communication substructures to take their place in the industrial production, leading to new work opportunities and enlarging the free time gaps of people. During these gaps, individuals take part in various activities presented to them in commericalized spaces (Önür, 2012:278). These entertaining activities take place in times outside of work, that is during free time.

When the uses and gratification theory is used to examine the role of new communication technologies, it presents an important theoretical perspective. Especially if we consider the internet to be part of one of the newest communication tools, it is natural to see that research has been done using the uses and gratification theory in order to understand pyschological behavioral tendencies of internet users (Papacharissi ve Rubin 2000:180-182).

The uses and gratification theory takes as its basic concept viewer activity/interactivity, due to the internet's interactive capability. This theory has the strongest theoretical framework to analyze the internet (Siraj 2007:403). Many researchers have proposed the uses and gratification theory as a method to understand why people use the internet and what kind of satisfaction they get from this use. With new media, there has been an increase in satisfaction. It is possible with the web 2.0 to own content, to update this content and to create new content. The user is active and thanks to this activity, there is interaction. The user's interactive activity comes before us with the notion of entertainment.

The concept of "network society" indicated by Castells, describes a value where the abundance of data, post-materialist values, consumerism, information and communication technologies and the unstoppable growth of the internet and social media reign. Society is developing and renewing itself along these lines. During the process of renewal and development the concept of technology as socialized information holds an improtant part. Technology has existed throughout time and will continue to exist. In today's world, one of the newest developments in technology is the concept of digitalization. In this context, technology encourages the digitalization of free time. As a result of the digitalization of free time, the concept of binge watching has come about. In today's world, social 
mechanisms such as this are finding new, digital identities. The transformation of conventional media into new media comes as one of the leading technological innovations. Before digitalization, uses and gratification come to the fore for the individual. The viewer becomes active with new media, able to use filtering options provided by new media's digital facilities, and, in accordance, they are able to relax, be satisfied and become socially interactive. It is not important for the viewer that what was once analogue is now digital. What is important for them is to access information quickly. This interaction is possible due to the system, which allows the viewer to appreciate itself, to have fun and feel excited and to socially interact.

Table 18. The Uses and Gratification Theory Process of Approach

\begin{tabular}{|l|l|l|}
\hline First step & User & Active \\
\hline $\begin{array}{l}\text { Second } \\
\text { step }\end{array}$ & New Media & $\begin{array}{l}\text { Filtering (socializing, entertainment, social } \\
\text { status, information) }\end{array}$ \\
\hline $\begin{array}{l}\text { Third } \\
\text { step }\end{array}$ & $\begin{array}{l}\text { Uses and } \\
\text { Gratification }\end{array}$ & Easement, satisfaction, social interaction \\
\hline
\end{tabular}

The digitalization of the mainstream is ongoing. Media systems are forming in coordinaton with the social, economic and political institutions of which it is a part of (Önür, 2012, s.288).

Kongar describes this situation as follows:

Communication has become globalized and monopolized in a manner never seen before in history. The priority of agents of production is to protect and develop their existence. Thus, news and information is produced and marketed in a way to fit their interests. The big weapon, food, drink or clothing companies running the world hold a significant role in this communication network. Obviously economic and political powers are interlocked. As a result, the system is focused not necessarily on the harmony of the news and information with reality, but more on how it is perceived by the masses (Kongar, 2014).

The approach "Whoever controls the media, controls the minds" has been underlined many times. Social relationships are being taken advantage of by capital along with the rapid development of communication technologies. However the problem here is not the rapid development of communication technologies, but rather the exploitation of social relationships relating to communication (Fuchs, 2014, p.112). According to Mosco, capitalism takes a hold of time and space. Binge watching is just one aspect of this situation. The abundance of interactive communication tools fills up every second of an individual's life. Debord's "The spectacle is the guardian of sleep" proposition falls in line with today's digital environment. Smart mobile technologies cause addiction in individuals due to their interactive communication characteristics. It is now easier for the system to control indidivuals because of technical facilities. New media, paired with science and technology, has become a toy for the global system. In this context, content is being produced for special technologies addressing the personal. These platforms push thought away from individuals and forces entertainment on them. In short, controlling new media means controlling various living spaces of people too.

According to Marx, economy reigns over all aspects of life, and is controlled by the political authorities. Media is needed for this system of control. Along with the digitalization of the media, the changes in forms of communication is making things complicated for individuals. Each new technology renews the individual. Alienation from the system is short lived. In time, new media is accepted and has nowadays become a vital part of life. New media is marketed by the economic system, and shown as new. The speed of the communication process is accepted by the individual, with its spaceless and networking characteristics. McLuhan's technological optimism overlaps with new media. According to this approach, new media is on its way of becoming the new intermediator of the economic system. In light of this information, the individual's mechanisms within the system are constantly renewed, along with technical developments. The individual becomes a slave of the system with its new mechanisms. For example, using Apple products is shown to be a privilege. Individuals give money for these products, which allow the system to watch them more easily. 
The Turkish Online Journal of Design, Art and Communication - TOJDAC January 2017 Volume 7 Issue 1

Individuals have learnt how to live in the public spaces defined by the system and will find out too late that they are left alone.

Spectacle presents itself as an indisputable and untouchable giant. "That which appears is good, and what is good appears" (Debord, 2006). The spectacle is the nightmare of imprisoned modern society which ultimately expresses nothing more than its desire to sleep. Private life is ending with the advent of new communication technologies. If a society has turned into a surveillance society, it means that that society no longer is being managed by a progressive agenda of the ruling class. At that point, science and technology are no longer the tools leading to freedom of revolutionary capitalism, but instead become the tools of destruction in a perishable capitalism. Individuals can now conduct their work from afar thanks to technological novelties, which leads to the disappearance of bodies. As a result of this disappearance, individual subjectivity leaves its place to objectivity.

\section{REFERENCES}

Arondekar, Anjali. 2005. "Without a Trace: Sexuality and the Colonial Archive." Journal of the History of Sexuality 14 (1 and 2): 10-27

Wehner, Mike. 2012. "Timeline Mandatory Rollout: You Have 7 Days to Scour Your Past." http://news.yahoo.com/blogs/technology-blog/facebook-timeline-mandatory-rollout7-days-scour-past-185456598.html Adorno, T. Kültür Endüstrisi: Kültür Yönetimi.[The Culture Industry] İstanbul: İletişim Yayınlarl, 2012.

Altunışık, R., Coşkun, R., Bayraktaroğlu, S. ve Yıldırım, E. Sosyal Bilimlerde Araştırma Yöntemleri. Sakarya: Sakarya Kitabevi, 2005.

Argan, M. Ĕglence Pazarlaması. Ankara: Detay Yayıncılık, 2007.

Bauman, Z. Küreselleşme: Toplumsal Sonuçları [Globalization: The Human Consequences] (Trans.: Abdullah Yılmaz). Istanbul: ayrintı Yayınları, 2012.

Arthur, B. Teknolojinin Doğasl. [The Nature of Technology: What It Is and How It Evolves]. (Trans.: İdil Çetin). Istanbul: Optimist Yayıncılık, 2011.

Bilgili, C. Medya Eleştirileri (Toplumsal Etkiler). İstanbul: Beta Yayınları, 2005.

Blanco, A. Dijital Çă̆da Boş Zamanın Dönüşümü, (Sosyal Medyada Devrim Kitabında Bölüm, Editör: Barlş Çoban) İstanbul: Su Yayınları, 2014, s.185-199

Büyükaslan, A. \& Kırık, A. Sosyal Medya Araştırmalar 1. Konya: Çizgi Kitabevi, 2013.

Cronbach, LJ. Essentials of Psychological Testing. Fifth Ed., New York: HarperCoIIins, 1990.

Demir, M. Yeni Medya Üzerine... Konya: Literatürk, 2013.

Erdoğan, I. Povitivist Metodoloji. Ankara: Erk Yayınlarl, 2003.

Erdoğan, I. ve Alemdar, K. Öteki Kuram-Kitle Iletişim Kuram ve Araştırmalarının Tarihsel ve Eleştirel Bir Değerlendirmesi. Gelişstirilmiş 2.Baskı, Erk Yayınları: Ankara, 2005.

Ellul, J. Teknoloji Toplumu (Trans.: )

Fiske, J. Illetişim Çalışmalarına Giriş [Introduction to Communication Studies] (Çev: Süleyman Irvan). Ankara: Pharmakon Yayınevi, 2013.

Fiske, J. Introduction to Communication Studies. London: Routledge, 3rd Edition, 2011.

Fuchs, C. Social Media: A Critical Introduction. Great Britain: Sage, 2014.

Gerbaudo, P. Twitler ve Sokaklar: Sosyal Medya ve Günümüzün Eylemciliği [Tweets and the Streets:

Social Media and Contemporary Activism]. İstanbul: Agora Kitapliğı, 2014.

Güngör, N. Illetişsim: Kuramlar ve Yaklaşımlar. Ankara: Siyasal Kitabevi, 2013.

Hepkon, Z. Iletişim ve Teknoloji: Olanaklar, Uygulamalar, Sinırlar. İstanbul: Kırmızı Kedi Yayınevi, 2011.

Karasar, N. Bilimsel Araştırma Yöntemi. Ankara: Nobel Yayın, 2009.

Katz, E., Blumler, J. G., \& Gurevitch, M. Utilization of Mass Communication by the Individual. In Katz, E., Blumler, J. G (Eds), The Uses of Mass Communication (pp. 19-32). Beverly Hills, CA: Sage Publications, 1974.

Katz, E., Gurevich, M., \& Hass, H. On the Use of the Mass Media for Important Things. American Sociological Review 38, 164-181, 1973.

Kellner, D. Medya Gösterisi [Media Spectacle] (Trans.: Zeynep Paşalı). İstanbul: Açıllım Kitap, 2010. 
The Turkish Online Journal of Design, Art and Communication - TOJDAC January 2017 Volume 7 Issue 1

Kolker, R. Media Studies: An Introduction. Wiley-Blackwell, 2009.

Lasn, K. Kültür Bozumu [Culture Jam] (Trans.: Cem Pekman, Ahmet Ilgaz). İstanbul: Băgımsız Yayinlar, 2004.

Kejanlıoğlu, B. Frankfurt Okulu'nun Eleştirel Bir Uğrağı: İletişsim ve Medya. Ankara: Bilim ve Sanat Yayinlarl, 2005.

Kejanlıoğlu, B. Türkiye'de Medyanın Dönüşümü. Ankara: Imge Kitabevi, 2004.

Laughey, D. Key Themes in Media Theory. Berkshire: Open University Press, 2007.

Lievrouw L. and Livingstone S. Handbook of New Media. London: Sage Publication, 2002.

Littlejohn, S. Ve Foss, K. Encyclopedia of Communication Theory. California: Sage, 2009.

Lister, M., Dovey, J., ve diğerleri. New Media: A Critical Introduction. New York: Routledge, 2003.

Manovich, L. The Language of New Media. Cambridge: MIT Press, 2001.

Massimo Baldini, İletişim Tarihi, Çev.,Gül Batuş, Avciol Basım Yayın, İstanbul, 2000, s. 5-6).

Mosco, V. ve Fuchs, C. Marx Geri Döndü: Medya, Meta ve Sermaye Birikimi (Çev: Funda Başaran).

Ankara: NotaBene Yaylnlarl, 2014.

Mutlu, E. İletişim Sözlüğü. Ankara: Ayraç Kitap, 2008.

Mutlu, E. Televizyon ve Toplum. 1.Basim, Ankara:Türkiye Radyo Televizyon Kurumu, 1999.

Oskay, Ü. 19. Yüzyıldan Günümüze Kitle İletişimin Kültürel İşlevleri. İstanbul: Der Yayınlarl, 2000.

Oskay, Ü. İletişimin ABC'si. İstanbul: Der Yayınları, 1997.

Önür, N. Toplumsal İlişkiler Sürecinde İletişim. (Kurumlara Sosyolojik Baklş, Editör: Sevinç Güçlü) Istanbul: Kitabevi Yayinları, 2012.

Rosenberry, J. \& Vicker, L. Applied Mass Communication Theory: A Guide for Media Practitioners. United States: Pearson Education, 2009.

Rosengren, K. E., Communication: An Introduction. London: Sage Publications, 2003.

Ruggiero, T. E. Uses and Gratifications in the 21st Century. Mass Communication and Society 3(1), 3-37, 2000.

Stevenson, N., Medya Kültürleri: Sosyal Teori ve Kitle Illetişimi. Ankara: Ütopya Yayınevi, 2008.

Severin, W., Tankard, J. Illetişim Kuramları: Kökenleri, Yöntemleri ve Kitle İletişim Araçlarında Kullanimları [Communication Theories: Origins, Methods and Uses in the Mass Media] (Çev: Ali Atıf Bir, Serdar Sever). Eskişehir: Anadolu Üniversitesi Yayınlarl, 1994.

Türkoğlu, N., Medya ve Toplumsal Dönüşüm: Seyirlik Cümbüşler. İstanbul: Parşömen Yayınları, 2012.

Uluç, G. Küreselleşen Medya: İktidar ve Mücadele Alanı. İstanbul: Anahtar Kitaplar, 2008.

Yaylagül, L. Kitle İletişim Kuramları: Egemen ve Eleştirel Yaklaşımlar. Ankara: Dipnot Yayınları, 2010.

Yengin, D. Dijital Oyunlarda Şiddet. İstanbul: Beta Yaynınları, 2012.

Yengin, D. New Media and Conversion of Reality. International Symposium Communication in the Millennium. Eskişehir. 318-331, 2010.

Yengin, D. "Televizyon ve Şiddet", Bülent Küçükerdoğan (Ed.), Televizyon ve. Ankara: Ütopya Yayinevi, 2009.

CBSLocal, 2014,

http://washington.cbslocal.com/2014/06/19/study-tv-violence-linked-to-imagined-fears-of-real-life-

crimel

Ntvmsnbc, 2014, "Çok TV izlemek erken yaşta öldürüyor"

http://www.ntvmsnbc.com/id/25523182/

Kongar, E. "Gerçek ve Algl", Cumhuriyet Gazetesi, 27 Haziran 2014,

http://www.cumhuriyet.com.tr/koseyazisi/87457/Gercek_ve_Algi.html\#

Turgut, S. "Dijital Alemden Bazl Önemli Trendler”, 01 Mart 2014.

http://www.mediacatonline.com/makale/dijital-alemden-bazi-onemli-trendler/) 